\title{
PORTER-ROMBUSZ: A REGIONÁLIS GAZDASÁGFEJLESZTÉSI STRATÉGIÁK ALAPMODELLJE
}

\author{
(Módszertani áttekintés)
}

\author{
(Porter's Diamond-Model for Regional Economic Development \\ Programming)
}

\section{LENGYEL IMRE}

\section{Bevezetés}

Az elmúlt években a globalizáció hatására a területfejlesztésnek mind elméleti háttere, mind programozási gyakorlata alapvetően átalakult. A formálódó posztmodern regionális politikában az alapvetỏ célok újrafogalmazódtak, a decentralizáció és a szubszidiaritás elveinek elfogadásával párhuzamosan az alulról szerveződő gazdaságfejlesztés került elötérbe. A posztmodern regionális politika különösen az Európai Unió (EU) területfejlesztésével foglalkozó dokumentumokban érhető tetten.

Az Európai Területfejlesztési Perspektíva (ESDP - European Spatial Development Perspective) a területfejlesztés hosszú távú céljaként három prioritást fogalmaz meg: a gazdasági és társadalmi kohéziót, a természeti erőforrások és a kulturális örökség megőrzését, valamint az európai térség kiegyensúlyozottabb versenyképességét (ESDP 1999, 10). Ez a célhármas megfelel a területfejlesztés hagyományosnak tekinthetö alapelveinek, a fenti sorrendben: méltányosság, fenntartható fejlödés, hatékonyság. Az EU-ban az elmaradott régiók gazdaságának fejlesztését célul kitüzö, a Strukturális Alapok és a Kohéziós Alap 2000-2006 közötti felhasználására szolgáló irányelveknél is a legfontosabb prioritás a regionális versenyképesség ösztönzése, amely két konkrét célra, a gazdasági növekedésre és a foglalkoztatottság javítására irányul (EC 1999/b). Így a regionális versenyképesség a hatékonyság (gazdasági növekedés) és a méltányosság (foglalkoztatottság) összekapcsolásával a regionális politika új, komplex alapelveként jelenik meg. Természetesen az EU irányelvei csak általános kereteket jelölnek ki a regionális versenyképesség javítására, mivel a támogatott régiók saját maguk dolgozzák ki fejlesztési stratégiájukat és programjaikat. Az EU dokumentumaiból az üzenet egyértelmü: a régiók gazdaságfejlesztésének célja a versenyképesség javítása, amelyre alulról felfelé szerveződő (bottom-up) gazdaságfejlesztési stratégiákat kell kidolgozni.

Magyarországon az elmúlt években, a Területfejlesztési és területrendezési törvény 1996. évi elfogadását követöen a megyék, de a kistérségek, valamint a formálódó régiók többsége is elkészítette területfejlesztési koncepcióját és területi programjait. Szinte mindegyik területfejlesztési koncepcióban a prioritások között szerepel az adott térség versenyképességének javítása, amelynek elérésére igen 
eltérố stratégiai programok születtek. A programkészitők elött általában két nehézség meruil fel ${ }^{1}$ :

1) a regionális/térségi versenyképesség fogalmának értelmezése és mérésének gondjai,

2) az alulról-felfelé szerveződó regionális gazdaságfejlesztési stratégiák módszertani kidolgozatlansága.

A fenti problémák megoldására tett kísérletek közül az egyik legismertebb Michael Porter megközelítése. Porter a globális folyamatokkal kapcsolatos eredményeit összegző alapvetỏ könyvében arra keresi a választ, hogy egyes országok a nemzetközi versenyben milyen tényezők miatt versenyképesek, mitől sikeresek, míg mások sikertelenek (Porter 1990). A vállalatok versenystratégiáival, a globális iparágakban ${ }^{2}$ folyó versennyel foglalkozó korábbi munkáira támaszkodva az egyes országok sikerességét visszavezeti a globális iparágakban mủködö, az adott országban hazai bázissal rendelkező vállalatok nemzetközi versenyben elért sikerességére (Porter 1985; 1993). Tíz országra kiterjedö, négy éven át tartó, szakértők és teamek sokaságát bevonó, közel 120 (nemzetközileg sikeres) iparágra kiterjedő empirikus vizsgálat ${ }^{3}$ eredményeit szintetizálta. Azt a következtetést vonta le, hogy a nemzetgazdaságok versenyelönyeinek kialakulásában és fenntartásában a globális vállalatok lokális és regionális üzleti környezete meghatározó szerepet tölt be. A versenyelőnyöket determináló üzleti környezet elemeit négy csoportba, az ún. „rombuszmodellbe" (diamond model) rendszerezte ${ }^{4}$. Az eredeti modellt a kilencvenes évek végén módosította, pontosította, a lokalitások szerepét még jobban elótérbe helyezte (Porter 1998a; 1999; 2000).

Porter gondolatai alapján egy régió alulról-felfelé szerveződő (bottom-up jellegü) gazdaságfejlesztési stratégiája a régióban mủkődő versenyképes vállalkozások és iparágak versenyelönyeihez szükséges helyi/regionális tényezők, azaz a rombuszmodell elemeinek fejlesztéséből állhat össze. Ebben a regionális gazdaságfejlesztési stratégiában az agglomerációs előnyöket kihasználó regionális klasztereknek kiemelkedő szerepük van ${ }^{5}$. Porter kezdeményezte a klaszter-alapú gazdaságpolitikákat is, amelyek egyre inkább elötérbe kerülnek a fejlett országokban (OECD 1999; Lengyel 2000a). A rombuszmodellt a lokális, regionális versenyképesség alapmodelljének is nevezik, amely nemcsak értelmezi a versenyképesség tényezőit, hanem egyúttal stratégiát is vázol javításukra (Malecki 1997; Maskell et al 1998). Magyarországon az utóbbi években kialakult a területfejlesztési koncepciók és területi stratégiák készítésének eszkőz- és módszertana (Horváth 1998; Rechnitzer 1998), minisztériumi rendelet is szabályozza kidolgozásukat, azonban úgy túnik, hogy az alulról felfelé szerveződő gazdaságfejlesztésnek még nem eléggé kiforrott sem a szemlélete, sem a gyakorlata.

A regionális gazdaságfejlesztési felfogások hátterében mindig a regionális gazdasági fejlődés különböző elméleti modelljei hủzódnak meg. Porter megközelítése több elméleti irányzatra vezethető vissza, részben Perroux növekedési pólus elméletére, részben a kumulatív oksági modellre (Armstrong-Taylor 2000), részben a gazdasági báziselmélet kiterjesztésére (Malizia-Feser 1999). Ebből is kitünik, hogy 
Porter nem az elfogadott közgazdaságtudományi és regionális tudományos kategóriákból és modellekböl kiindulva próbálta magyarázni a globális folyamatokat, hanem fordítva, nagyméretü empirikus iparági vizsgálatok eredményeit szintetizálva eredeti összefüggéseket fogalmazott meg. Emiatt munkássága megosztja a tudományos közvéleményt, a stratégiai menedzsmenttel foglalkozók és a vállalati szakemberek ,istenítik”, míg az elméleti közgazdászok kevésbé értékelik munkásságát, „tudománytalannak” tartva egyes megállapításait (Török 1997). Azt viszont mindenki elismeri, hogy Porter meglátásai és gondolatai konzisztens rendszert alkotnak, amely napjainkra az általános közgazdasági és üzleti mủveltség része lett. A rombuszmodell olyan önálló és eredeti fogalmakra, állításokra épül, amelyek eltérnek a regionális tudományban használtaktól, viszont ismeretük nélkül a rombusz alkalmazása félreértésekre vezethet, amire itthon is több példa található. A félreértések részben arra vezethetők vissza, hogy eddig nem volt részletes és alapos magyar nyelvü áttekintés a modellröl.

Tanulmányunkban Michael Porter rombuszmodelljét ismertetjük a regionális gazdaságfejlesztési stratégiákban történö alkalmazhatóságát szem elött tartva. A dolgozat elsö részében a globális folyamatok jellemzöit vázoljuk és azon ủj fogalmakat, állitásokat, amelyekböl Porter is kiindult. Ezt követően a rombuszmodellt és determinánsait olyan mélységben és részletességgel mutatjuk be, amely megítélésünk szerint a modell gyakorlati alkalmazásához kellö segítséget nyújthat. Röviden kitérünk a rombuszmodell alapján megfogalmazott klaszterekre, valamint Porter szakaszos fejlődési modelljére is. A dolgozat végén áttekintjük a régiók bottom-up gazdaságfejlesztési stratégiai programozásának föbb szempontjait és röviden értékeljük a rombuszmodellt.

\section{Versenyképesség és termelékenység}

Egy ország, régió, város fejlödésének és fejlesztésének alapvetö célja Adam Smith óta általánosan elfogadott: az ott élök jólétének, életszinvonalának és életminőségének javítása (Enyedi 1996). Ez pedig Porter szerint a globalizációban nem a termelési tényezökböl adódó komparativ elönyöktöl, hanem az ország/régió versenyképességétöl függ. Rögtön felvetödik a kérdés, mit értünk versenyképesség alatt és milyen tényezök befolyásolják?

A versenyképesség a közgazdaságtudományban régóta használt fogalom, általában a vállalatoknál a piaci versenyben való helytállást, az országoknál, régióknál a nemzetközi versenyben való sikerességet jelenti (Török 1997). Az elmúlt két évtizedben, a globalizáció felerősödésével a versenyképesség vált az egyik kulcsfogalommá, amellyel az új feltételek közötti globális verseny jelenségeit, a versenyben való sikeres részvételt próbálják leírni mind a vállalatok, mind az országok és régiók esetében. A globalizáció nemcsak a nemzetgazdaságok jelentőségét mérsékelte, hanem a régiók gazdasági szerepét is felértékelte. Elfogadottá vált, hogy a globális verseny lényegében az egyes régiók, nagyvárosok versenye, külö- 
nösen az EU-ban nyert teret ez a szemlélet a decentralizációval és a regionális identitások felerősödésével együtt.

A versenyképesség fogalmának pontosítására való törekvés a globalizáció megerösödésével vált egyre érzékelhetőbbé (Lengyel 2000b). A globalizáció két alapvetö folyamata, a dereguláció kibontakozása és a kommunikációs-informatikai technológiák, technikák elterjedése egyre kevésbé tették, teszik lehetővé a nemzeti kormányok számára, hogy közvetlenül befolyásolják a nemzetközi versenyt hagyományos eszközeikkel (pl. exporttámogatások, vámok és illetékek stb.), ezért kerültek elötérbe a közvetett módszerek és eszközök. Ezek a közvetett módszerek a vállalatok versenyelỏnyeit meghatározó háttérfeltételekre, azaz elsősorban a versenyképességet befolyásoló üzleti, intézményi és infrastrukturális környezet tényezőinek javítására irányulnak. A versenyképesség egy gyüjtőfogalom, első megközelítésben a piaci pozíció megszerzésére, megtartására és javítására való hajlamot, a piaci versenyben valo helytállás képességét, az üzleti sikerességet jelenti.

Porter szerint az országok versenyképességének mérésére használt szokásos gazdasági mutatók (exportrészesedés, külkereskedelmi mérleg, valuta árfolyam stb.) féloldalasak, a globális versenynek csak egy-egy vetületét fejezik ki, az országok széles körében nem alkalmasak a „versenyképesség” lényegének mérésére. A pozitív külkereskedelmi mérleg, az alacsony költségvetési deficit (Olaszországra a nyolcvanas években nem volt igaz), az olcsó munkaerő (Németországra, Svájcra nem teljesül), a természeti eröforrások bősége (Japánra nem igaz) stb. csak részigazságokat fejeznek ki, az egyes országok nemzetközi versenyben való sikerességének mérésére nem alkalmasak. Ráadásul a versenyképesség fogalma többértelmü, mivel mást értenek rajta a vállalati szakemberek (a világpiacon érvényesithető vállalati versenyelönyöket), mást a politikusok (az ország pozitív külkereskedelmi mérlegét) és mást az elméleti közgazdászok (többségük a munkatermelékenységet) (Porter 1990, 12). A lényeg az, hogy a sikeres országokban nö a termelékenység, az egységnyi alkalmazott inputra (ráfordításra) jutó reálkibocsátás, amelynek növekedése a tỏke és/vagy munka hatékonyságának növekedéséből származik. Egy nemzet alapvető gazdasági célja polgárai számára magas és növekvő életszínvonal teremtése, amely nem ,... a versenyképesség amorf fogalmától függ, hanem a termelékenységtől, a nemzet eröforrásainak (munka és tőke) felhasználásától. ... A versenyképesség egyetlen értelmezhető koncepciója nemzetgazdasági szinten a nemzeti termelékenység" (Porter 1990, 6).

A fentiek miatt Porter szerint az országok versenyképessége nem más, mint a globális versenyben elért termelékenység magas szintje és magas növekedési üteme. A versenyképesség fogalmát visszavezette egy közismert, nagyon alaposan elemzett közgazdasági kategóriára, a termelékenységre ${ }^{6}$. Így Porter nem javasolt új fogalmat, nem kreált új mutatórendszert, hanem a versenyképességet a gazdasági fejlödést hosszabb távon meghatározó elméleti fogalommal, a termelékenységgel azonosítja.

A kilencvenes évek végére egyre szélesebb körben elfogadottá vált, föleg az OECD és az EU szakértöi munkabizottságaiban, hogy mind vállalatokra 
(mikroszintre), mind iparágakra és régiókra (mezoszintre), mind nemzetgazdaságokra (makroszintre) a versenyképesség egységesen értelmezhetö fogalomként is megadható (Maskell et al 1998; Lengyel 2000b). Az egységes/kiterjesztett versenyképesség fogalom: „,... a vállalatok, iparágak, régiók, nemzetek és nemzetek feletti régiók képessége relative magas tényezöjövedelem és relative magas foglalkoztatottsági szint tartós létrehozására, miközben a nemzetközi (globális) versenynek ki vannak téve" (Hatzichronoglou 1996; EC 1999a; 20). A regionális versenyképesség nem más, mint magas fajlagos kibocsátás (egy lakosra jutó GDP), amely egyaránt származik a munkatermelékenység és a foglalkoztatottság magas szintjéből (Lengyel 2000b; Lengyel-Rechnitzer 2000).

A versenyképességet Porterhez hasonlóan Paul Krugman is inkább gazdaságpolitikai fogalomnak tartja, míg a gazdasági növekedés alapkategóriája a termelékenység (Cséfalvay 1999; Lengyel 2000b). Mindketten kiemelik, habár a megtermelt jövedelem egy részét a jövedelemtulajdonosok kivonhatják a régióból, de a régióban maradó jövedelem nagyságának változása hosszabb időtávban együtt mozog a termelékenységgel, így az életszínvonal tartósan a termelékenységtől függ. Gondolatmenetük érthető abból a szempontból is, hogy gazdasági erőtérböl kiindulva nem közigazgatási, hanem csomóponti régiót feltételeznek, amelynek nem adható meg pontos földrajzi határa, így pl. a foglalkoztatottsági ráta sem számítható ki. Ha a foglalkoztatottságtól eltekintünk, akkor viszont hasonlóság van Porter felfogása ${ }^{7}$ és az egységes versenyképesség fogalma között, mivel utóbbi a közigazgatási régiókra lett kidolgozva.

A régió gazdaságfejlesztésének célja a versenyképesség növelése, azaz a régióban müködő gazdasági szervezetek termelékenységének javitása. Porter szerint nem a versenyképességet kell magyaráznunk, hanem meg kell értenünk, hogy mi határozza meg a termelékenységet és növekedési ütemét (Porter 1998a, 161). Porter felfogása egyértelmủen ,stratégiai”, azaz nem bemutatni kell egy régió gazdaságát, hanem feltárni azokat a mozgatórugókat, amelyek kihasználására fejlesztési stratégia épülhet. Egy régióban a gazdasági szektorok termelékenységének változása eltérő ütemú, a külkereskedelembe (globális piacra) kerülö (tradable) termékeket és szolgáltatásokat elóállitó ágazatokban az erőteljes verseny miatt gyorsan javul, míg a helyi (hazai, regionális) piacra kerülö (nontradable) termékeknél és (föleg lakossági) szolgáltatásoknál a termelékenység javulása lassúbb ütemü. Nyilván az utóbbi termékeknél a helyi kereslet korlátozott, míg a globális piacon a méretgazdaságosság miatt növekvő skálahozadék érhető el, ezért a termelékenységet nỏveló új technológiák és innovációk bevezetése szinte folyamatos a globális verseny erös nyomása miatt.

Porter a versenyképességet visszavezette a termelékenységi szintre és a termelékenység növekedési ütemére, amit föleg a globális versenyben lehet elérni. Kérdés, milyen tényezőktől függ egy régióban a termelékenység növekedése? 
1. ÁBRA

A termelékenységnek és növekedési ütemének determinánsai

(Determinants of Productivity and Productivity Growth)

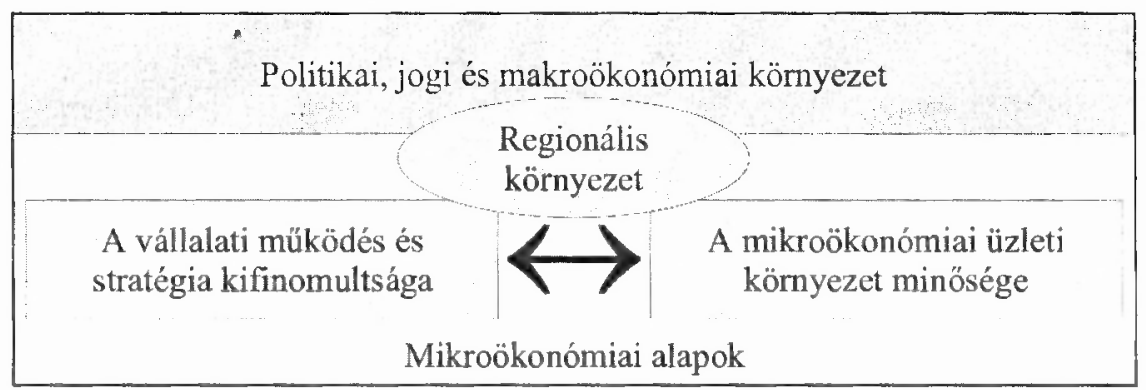

Forrás: Porter $(1999,31)$ ábrájának módosításával saját szerkesztés.

A termelékenységet, azaz a versenyképességet a makroökonómiai környezet és a mikroökonómiai alapok egyaránt befolyásolják (I. ábra). Porter a politikai, jogi és makroökonómiai környezet jelentőségét ủjabban fogalmazza meg (korábban a mikroökonómiai háttéret helyezte elötérbe), mivel a gazdaságpolitika, monetáris politika, adótörvények, befektetések szabályozása, társadalombiztosítás, innovációs rendszerek, szerzői és jogvédelem, oktatási rendszerek stb. országonként eltérỏ módon determinálják a termelékenység alakulását (erre mutattak rá a kilencvenes évek távol-keleti válságai, valamint a fejlődő országok problémái). Nevezetes 1990es könyvében a kormányzat mintegy másodlagos szerepet játszott a rombuszmodell determinánsainak befolyásolásában, viszont napjainkra a makroökonómiai környezet kiemelt fontosságúvá vált (ennek részeként a kormányzat is), amely az iparágak versenyképességének javítását nagymértékben képes segíteni, de hátráltatni is.

A mikroökonómiai alapok egyrészt a vállalati múködés és stratégia kifinomultságát jelentik, másrészt a mikroökonómiai üzleti környezet, föleg a lokális üzleti környezet minőségét. Ezáltal Porter megkülönbözteti a vállalaton belüli (vállalati döntéstől függő) és a vállalaton kívüli (vállalati döntéstől független) tényezőket, viszont mindkettőt egyaránt fontosnak tartja. A vállalaton belüli tényezők erössége, a vállalati mủködés és versenystratégia kifinomultsága, a menedzsment felkészültsége, az alkalmazottak kreativitása nélkül a globálisan versengó vállalatok nem tudják megőrizni versenyelőnyeiket, sőt minőségi vállalati jellemzők hiányában a régió vezető vállalatai nem is tudnak kilépni a globális piacra. Tehát egy régió gazdasági növekedésében a vállalatok mủködését és stratégiáját formáló menedzsereknek és szakértöiknek kiemelkedö a szerepük, sőt kijelenthetjük, hogy a régió fejlödése szempontjából jóval fontosabb döntéseket hoznak, mint pl. a megyei és települési önkormányzatok vezetô testületei. Söt egy megye, város akkor fejlődik tartósan, ha az önkormányzati fejlesztések legföbb célja a vállalatok termelékenységének javitása, amely hosszabb távon csak fenntartható környezeti fejlődés és stabil szociális háttér mellett valósulhat meg.

Porter a mikroökonómiai üzleti környezet tényezöit a később részletesen ismertetendő rombuszmodellben rendszerezte. Véleményünk szerint a termelékenység 
javításához célszerü kiemelni a regionális környezetet is, amely mind a makroökonómiai környezethez, mind a mikroökonómiai alapokhoz szorosan kapcsolódik. A regionális, települési környezet sikeressége összefügg az ott múködő vállalatok, iparágak versenyképességével (Enyedi 1997). A regionális környezet a termelékenység növekedésének mindegyik tényezőcsoportját befolyásolja, azok egyféle közös részét képezi:

- A regionális környezetnek vannak olyan elemei, pl. a régióban a hálózati infrastruktúra fejlesztése, a regionális innovációs rendszer, a települések oktatási intézmény-fejlesztése stb., amelyek a regionális/megyei/települési politika részei, viszont jellegüknél fogva a makroökonómiai környezethez tartoznak.

- A vállalati müködés és stratégia kifinomultsága nemcsak magától a vállalattól függ, hanem a környezetében domináns viselkedési mintáktól, a helyi tudásbázistól, a helyi munkakultúrától stb., azaz hatással van rá a regionális/lokális környezet is.

- A mikroökonómiai üzleti környezet tényezői pedig jórészt lokálisak és regionálisak, pl. a helyi beszállítói hálózatok, helyi szakképzési intézmények stb., amelyek jóval túlmutatnak egy-egy vállalat igényein.

Egy régióban a termelékenység egyaránt függ az országos és regionális környezettöl, valamint a mikroökonómiai alapoktól. A regionális gazdaságfejlesztés során természetesen csak a regionális környezetet lehet befolyásolni, elsősorban a mikroökonómiai üzleti környezet (rombuszmodell) elemeit, míg a vállalati müködés és stratégia kifinomultságát fóleg oktatással és regionális klaszterek létrehozásával és támogatásával lehet javítani. A rombuszmodell előtt röviden áttekintjük a globális verseny és a versenystratégiák témakörünkbe tartozó azon legfontosabb fogalmait és gondolatait, amelyekre később támaszkodunk.

\section{Globális iparágak, regionális specializáció, hazai és térségi bázis}

Porter egész gondolatrendszere a globális iparági versenyre és a versenystratégiákra épül, szerinte minden vállalati stratégia egyben versenystratégia. A vállalatok fó célja versenyelönyök megszerzése és fenntartása. A piaci verseny „két vagy több szereplő egymással szembeni előnyszerzésre irányuló, adott szabályok között zajló tevékenysége" (Chikán 1998, 98). Így versenyelöny alatt az üzleti vállalkozásoknak a piaci versenyben szerzett elönyét értjük, ami elsősorban olyan tevékenységek végrehajtásából adódik, amit a vállalat másoknál jobban tud elvégezni.

A vállalati versenyelőny keletkezése a szélesen értelmezett innovációktól, az új üzleti lehetöségekre adott gyors és hatékony válaszoktól függ, forrásai (Porter 1990, 45-47):

- új technológia bevezetése,

- új vásárlói igények vagy a fogyasztói prioritások változásának felismerése,

- új iparági, piaci szegmens kialakulása,

- az input költségének vagy elérhetőségének változása,

- a kormányzati gazdaságpolitika változásai. 
Piacgazdaságban a régió gazdaságfejlesztésének közvetett célja a termelékenység javítása, mig közvetlen célja olyan regionális környezet, föleg mikroökonómiai üzleti környezet kialakítása és fenntartása, amely a régióban müködő vállalatok versenyelönyeit tartósan biztosítja. A globalizáció során mind a vállalati versenynek, mind a versenyelönyöknek új sajátosságai kerültek felszínre, illetve a régi jellemzök közül néhány dominánssá vált.

Porter kutatásai és munkái ${ }^{8}$ alapján öt állítás fogalmazható meg, amelyekre a rombuszmodell és a klaszterek is támaszkodnak (Porter 1990; 1998a; 2000):

(a) Globális iparági verseny: a piaci verseny az egyes iparágakon belül folyik, azaz ugyanazon iparágon belül müködő vállalatok, vállalatcsoportok között.

(b) Értéklánc-rendszer: a vállalatok nem elkülönülten versenyeznek, hanem sokféle módon kapcsolódnak egymáshoz az értékteremtö folyamatban.

(c) Regionális specializáció: egyetlen ország/régió sem lehet versenyképes mindegyik globális iparágban, így a régiók gazdasága erőteljesen szakosodik néhány iparágra/üzletágra.

(d) Innovációs kapacitás: egy ország/régió termelékenységének (versenyképességének) javulása a régióban múködő domináns iparágak innovációs kapacitásától függ.

(e) Hazai és térségi bázis: az országok/régiók globális iparágai földrajzilag koncentrálódnak néhány, gyakran egy-két régióban, legtöbbször nagyvárosokban és vonzáskörzetükben.

A fenti állítások kapcsolódnak egymáshoz és részben átfedések is vannak. Csak röviden térünk ki a bennük megfogalmazott olyan alapvető gondolatokra és fogalmakra, amelyek a regionális tudománnyal foglalkozók körében itthon kevésbé terjedtek el, viszont megítélésünk szerint ismeretük elengedhetetlen a rombuszmodell alkalmazói szintü megértéséhez. Fontosnak tartjuk, hogy a stratégiai menedzsment és vállalatgazdaságtan kifejezéseire és gondolataira épüljenek egy régió gazdaságfejlesztési stratégiai programjának azon részei, amelyet a vállalatok valósítanak majd meg, mivel ezt a „szakzsargont” értik a kulcspozícióban levő vállalati vezetôk és szakértök.

Megjegyezzük, hogy napjainkban a nemzetközi munkamegosztásra Porter szerint a komparatív elónyök elmélete nem ad elfogadható magyarázatot (Porter 1990). Nemcsak a Leontief-paradoxon figyelhetö meg, hanem a komparatív elönyök elmélete nincs tekintettel a méretgazdaságosságra, a technológia és a kapcsolódó know-how jelentőségére, a termékdifferenciálásra és a monopolisztikus piacokra, a vállalati hálózatok és stratégiai szövetségek megerősödésére, valamint állandónak tekinti egy országon belül a termelési tényezöket és nem foglalkozik a termelési tényezök (töke, munkaerő) országok közötti áramlásával. A fentiek miatt a komparatív elönyök elméletét tovább kell fejleszteni, döntően azon globális vállalatok versenystratégiájából kiindulva, amelyek egy-egy iparágat megjelenítenek a nemzetközi versenyben, és amely vállalatok az innovációk kidolgozásában és alkalmazásában, a technológiák fejlesztésében, a termékdifferenciálásban, a kormányzati politikák befolyásolásában stb. élen járnak. Porter javaslata ezen továbbfejlesztésre 
a kompetitív elönyök elmélete, amely a nemzetközi (és regionális) munkamegosztás új tényezöit rendszerezi.

\section{Globális iparági verseny}

Porter szerint piaci verseny ugyanazon termékpiacon termékkel, szolgáltatással megjelenő vállalatok között folyik, azaz a piaci verseny mindig iparágon belül folyó versenyt jelent. Az iparág kifejezés alatt nemcsak feldolgozóipart értünk, hanem bármilyen üzletágat is, azaz olyan elkülönüló termékpiacokat (pl. szórakoztatóipar, pénzügyi szolgáltatások, reklámipar stb.) is, amelyek a gyakorlatban nagyon sokszinủen jelennek meg, esetenként nem egyértelmủen határolhatók el egymástól és általában nem igazodnak a statisztikai nyilvántartások (ISIC, NACE) ágazati besorolásaihoz.

A globális iparágon/üzletágon beliul a vállalatok között folyó verseny több jellemzője eltér a korábbi évtizedekben megfigyelt nemzetközi versenyétöl. A tartós versenyelőnyöknél különösen az alábbi tényezők váltak fontossá:

(a) A technológiai váltás mindent áthat, folyamatos, és mindegyik iparágban, mindegyik vállalatnál a verseny kikényszeríti az új technológiák bevezetését (pl. a mikroelektronika, az információs rendszerek, az automatizálás, új alapanyagok stb. mindegyik vállalatnál döntőek), a legújabb technológia alkalmazása jóval fontosabb, mint az olcsó munkaerö.

(b) A hagyományos termelési tényezőknél az országok és régiók között bizonyos területi kiegyenlítödési folyamat zajlott le (pl. az alapvetö hálózati és energetikai infrastruktúra, a közoktatás, a közegészségügy stb. mindenütt kiépült), napjainkra nem a mennyiségi, hanem a speciális minöségi tényezők váltak fontossá, a versenyelönyök elsődleges forrásává (pl. nem a munkaerỏ mennyisége, hanem minősége, képzettsége, munkafegyelme, kreativitása stb. a döntö).

(c) A globális vállalatok szinte az egész világon eladnak és inputjukat bárhonnan beszerezhetik, ezek a vállalatok függetlenedtek országuk tényezöellátottságától (nyersanyag, munkaerö stb.) és a termelést a legelönyösebb helyre, több esetben a piacokhoz közel telepítik.

(d) Az alacsonyan képzett munkaeröre vagy a természeti eröforrásokra (pl. mezögazdaságra) épülő iparágak fejlesztéseinek átlagos megtérülési rátája alacsony (amint az a fejlödő országokban megfigyelhetö), mivel sok országban adottak ezek a lehetöségek, általában alacsonyak a piacra lépési korlátok, ezért egyre több vállalkozás lép a piacra, ezáltal letörik a profitot és az erös verseny következtében lenyomják előbb-utóbb a munkabéreket is.

(e) Nem elkülönült, nem izolált vállalatok versenyeznek a piacon, hanem kooperáló, különbözö mértékben együttmüködö, egymástól kölcsönösen függö szervezetek: vállalati hálózatok, stratégiai szövetségek stb., a vállalati kooperációkkal a finanszírozó pénzintézetek is szoros kapcsolatban állnak, amely intézetek közös érdekeik védelmében a vállalati versenystratégiákat is befolyásolják. 
A globális vállalatok tartós versenyelőnyeinek kialakulásában és fenntartásában kiemelkedô jelentőségűvé vált:

(a) A méretgazdaságosság: melyik nemzet vállalatai melyik iparágban tudják növelni a termelés méreteit, kihasználva a globális igényeket, ezáltal csökkentve a fajlagos költségeket (az átlagköltségeket), több esetben a szük hazai piac miatt lépnek ki vállalatok a világpiacra.

(b) A technológia szerepe: amelyik vállalat elöször használ egy új technológiát, az kezdetben monopolhelyzetbe kerül, magas profitra tesz szert, valamint megnövelheti a gazdaságos tömegtermelés méretét. A technológia megújítására állandóan törekedni kell, mivel a követők elöbb-utóbb bezárják a „,technológiai rést", utolérik a vezető vállalatot.

(c) A nagy és erösen szegmentált belfóldi piac megléte: amely lehetővé teszi erös verseny kialakulását több hazai cég között. A verseny következtében szükséges, a piac nagy mérete miatt pedig érdemes fejlesztéseket elindítani, mivel megtérülnek a befektetések, általában a belső piac telítódése után indul be az export.

(d) A multinacionális társaságok elönyeinek kihasználása, amelyek több országban müködtetik érdekeltségeiket és lehetöségük van az országok közötti eltérö gazdasági feltételek, a profitcentrumok és transzferárak, helyi adózás stb. kiaknázására is.

A globális versengés tényezöi jelentösen eltérnek iparáganként, pl. az iparágra jellemzö technológia hatásai csak egy adott iparágon belül vizsgálhatók. Az empirikus vizsgálatok szerint pl. az élelmiszeripar, a fa- és bútorgyártás több iparága kevésbé „,nemzetköziesedett”, mint a számítógép-, az autó-, a gyógyszergyártásé stb. (Hatzichronoglou 1999). A globális vállalatok közötti verseny mindig iparágon belüli verseny, így a versenyelönyök keletkezésének mechanizmusát iparágon belül kell vizsgálni. Egy iparágon belül folyó versenyben a vállalat kialakítja versenystratégiáját, amely pozicionáláson és értékteremtésen (és imázsteremtésen) alapszik. Porter szerint a versenyelönynek két alaplehetősége van (Porter 1985; Chikán 1998, 498-500):

- a költségelöny, az alacsony költségek miatti alacsony árból adódó versenyelöny,

- a termékdifferenciálásból adódó elöny, a termékek megkülönböztetésén, egyediségén, egyedi minöségén alapuló versenyelöny.

Mindkét alaplehetőség esetében a versenystratégiák függnek a célba vett piac terjedelmétöl (a piaci célterület széles avagy szük). Széles piaci célterület esetében a költségelőnyön alapuló stratégia vagy alacsony árat és nagy piaci részesedést céloz meg (nagy forgalom, kis fajlagos haszon), vagy magasabb árat és kisebb piaci részesedést (kis forgalom, nagy fajlagos haszon). Szük piaci skálán költségelönyt a költségek fókuszálása, az árérzékeny egyedi fogyasztókhoz történő igazítása jelent. A termékdifferenciálás stratégiája a kevésbé árérzékeny fogyasztók megnyerését célozza, a termék egyedülálló minőségén, speciális jellemzőin, a kapcsolódó szolgáltatások 
megbízhatóságán stb. alapszik. Szintén megkülönböztetjük a nagy piaci részesedésre törekvö, valamint a fókuszált, azaz egyedi igényeket kielégítő termékdifferenciálást.

A globális iparági versenyből adódik, hogy egy régió gazdaságának helyzetértékelését a gazdaságfejlesztési stratégiai programozás során két lépésben kell elkészíteni:

1) fel kell tárni, hogy a régió iparágai közül melyek vesznek részt a globális versenyben,

2) globális iparáganként külön-külön meg kell vizsgálni, hogy versenyelönyeik miból erednek.

\section{Értéklánc-rendszer}

Mindegyik vállalat gazdasági tevékenységek sorozatát végzi, miközben egy-egy terméket elöállít, vagy szolgáltatást ellát. Alapkérdés, hogy milyen tevékenységet végezzen maga a vállalat és milyen tevékenységet végeztessen el mạ́s vállalatokkal, beszállítókkal, szolgáltató cégekkel stb. A vállalatnak azokat a tevékenységeket célszerü elvégeznie saját részlegeiben, amelyekben jobb a versenytársainál és versenyelőnye van, amiben pedig nincsenek versenyelönyei, avagy veszteségei keletkeznek, azokat a tevékenységeket érdemes másokkal elvégeztetnie. Az erös globális verseny miatt a korábbi nagyvállalatok felbomlottak, átalakultak, csak úgy tudtak talpon maradni, ha profiltisztítást hajtottak végre.

A potenciális versenyelőnyök meghatározásához a vállalati tevékenységeket el kell különíteni egymástól, ehhez Porter az ún. értékláncot javasolja, amely a vállalaton belüli tevékenységek értékalkotó összekapcsolódását jelenti. Porter kilenc vállalati értékteremtő tevékenységet különböztet meg két nagyobb típusba sorolva, amelyek együttes hatásaként adódik a hozzáadott érték nagysága (Chikán 1998, 159; Porter 1998a, 314):

1) Az elsödleges tevékenységek:

- (A) a bemenő logisztika: beérkező anyagok raktározása, adatgyüjtés stb.

- (B) termék elöállitás (gyártás): alkatrész(alkotóelem)gyártás, összeszerelés, részlegek múködtetése,

- (C) kimenő logisztika: megrendelések feldolgozása, késztermékek raktározása stb.

- (D) marketing és értékesítés: eladási erőfeszítések, reklámozás, termék bemutatók, felhasználási javaslatok stb.

- (E) értékesítés utáni szolgáltatások: üzembe helyezés, felhasználók támogatása, panaszok kezelése, javítás stb.

2) Támogató, vagy kiegészitő tevékenységek:

- (a) a vállalati infrastruktúra: pénzügyek, tervezés, befektetöi kapcsolatok stb.

- (b) humán eröforrás menedzsment: toborzás, képzés, ösztönzési rendszer stb.

- (c) technológiai fejlesztés: terméktervezés, alapanyag-kutatás, tesztelés, gyártástervezés, piackutatás stb.

- (d) beszerzés: alkatrészek, gépek, szolgáltatások stb. 
A támogató, kiegészitö tevékenységek mindegyik elsődleges tevékenységhez kapcsolódnak (kapcsolódhatnak), azok részeit alkothatják. A legjobb versenyelönyök meghatározásakor a vállalat feladata az, hogy elemezze az elsődleges értékteremtő tevékenységek költségeit, fejlesztési lehetőségeit, összehasonlítva az iparági versenytársakéval. A vállalat egy adott értékteremtö tevékenységnél akkor rendelkezik versenyelőnnyel, ha a versenytársainál hatékonyabban képes elvégezni ezt a tevékenységet úgy, hogy a vásárlók ezt hajlandók meg is fizetni. A vállalat dönthet úgy, hogy a kevésbé előnyös tevékenységeket megszünteti és beszállítókkal oldja meg (outsourcing), avagy külföldre telepíti pl. a gyártást, ezáltal a vállalatnál csak a tartós versenyelönnyel bíró tevékenységek maradnak. Természetesen az értéklánc elemei és a köztük levő kapcsolatok, a beszállitói kör kialakítása, a tevékenységek külföldre telepítése stb. erősen iparág specifikusak.

A globális vállalatnál ugrásszerüen megnőnek a tranzakciós költségek (különböző országok eltérỏ piaci szabályozása, a sok telephely koordinációja stb. miatt), az ilyen vállalat csak akkor tud versenyben maradni, ha ezeket a költségeket minimalizálja a tevékenységének legjobban megfelelő szervezetet kialakítva, több esetben az értéklánc egyes elemeit külföldre kihelyezve. A globális versenystratégiákban a nemzetközi szintủ versenyelönyök elérésének két, egymást kiegészitő alapvetö módja van:

(a) A globális vállalati szervezet kialakítása, amikor alapkérdés, hogy egy nagy üzemet tartsunk-e fenn, avagy elkülönült telephelyek hálózatát. Az alapesetek:

- a tevékenységek koncentrálása egy üzembe, és onnan exportálni a végterméket (pl. a repülögépiparban gyakori), ekkor a tevékenységek a vállalat központi üzemében folynak, előny származik a koncentrált kapcsolatokból, az egységek közötti gördülékeny együttmüködésböl,

- a tevékenységek szétteritése, föleg olyan iparágakban, ahol a telepitési tényezök térben egyenletesen találhatók, a szállítási, raktározási költségek magasak, és döntő a fogyasztóhoz való közelség, nagy a kommunikációigény (pl. a szolgáltatások többségénél), a vállalati központban általában a stratégiai döntések, a $\mathrm{K}+\mathrm{F}$ tevékenység, a marketing koordinálása, a pénzügyi döntések stb. maradnak,

- a tevékenységek telepitése egyedi feltételekre, több iparág esetében egy-egy város, régió kompetitív elönye (magasan képzett munkaerő, kutatóintézetek, egyetemek stb.) miatt egyes speciális tevékenységeket célszerủ olyan helyre telepíteni, ahol a szinergia és agglomerációs hozadék következtében a versenyelőnyök erösek és stabilak.

(b) A globális koordináció kialakítása a vállalat üzleti partnerei (az értékláncrendszer egyes résztvevői) között, hogy mindenkihez eljussanak azok az információk, tapasztalatok, innovációk stb., amelyek a versenyelönyök fenntartásához szükségesek.

A vállalatok láncszerúen kapcsolódnak egymáshoz, a végső fogyasztói igény kielégítésére szolgáló termék több vállalat (alkatrészelöállítók, alapanyagszállítók, berendezések előállítói, kereskedők stb.) összehangolt, specializált munkájából áll 
elö, amely koordinációt az iparághoz tartozó vállalat (mint integrátor) végzi el. Emiatt a vállalatnak saját értékláncán kívül a beszállítói, viszonteladói és vásárlói értékláncokat is vizsgálnia kell. Egy adott vásárlói igény kielégítése során a munkamegosztásból kialakuló, egymáshoz kapcsolódó vállalati értékláncok egy értéklánc-rendszert ${ }^{9}$ alkotnak (2. ábra). Az értéklánc-rendszer az egyes vállalati értékláncok összekapcsolásából létrejövö, a végsö fogyasztó kiszolgálására szervezödö lánc. Nyilvánvalóan nagyon eltérö, időben is gyorsan változó értéklánc-rendszerek vannak, a vertikumoktól és stabil beszállítói kapcsolatoktól kezdve az eseti beszerzéseken, egyedi szerződéseken alapuló kapcsolatokig.

\author{
2. ÁBRA \\ Az értéklánc-rendszer \\ (The Value System)
}

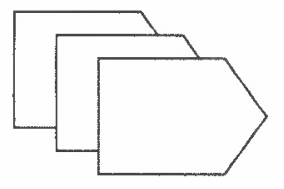

támogató értékláncok

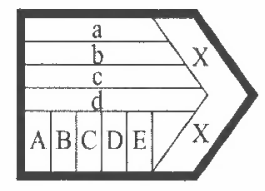

vállalati értéklánc

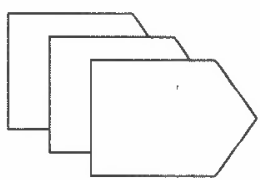

elosztó értékláncok

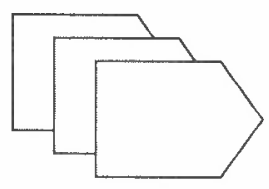

vásárlói értékláncok

Megjegyzés: a vállalati értékláncban az elsödleges tevékenységek: (A),(B),(C),(D) és (E); a támogató tevékenységek: (a),(b),(c) és (d); míg a hozzáadott érték: (X).

Forrás: Porter $(1990,43)$ felhasználásával saját szerkesztés.

$\mathrm{Az}$ értéklánc-rendszer mindegyik tagja abban érdekelt, hogy a végső fogyasztỏi igények minél teljesebben legyenek kielégítve, azaz együttmüködésre, egymás segítésére kell törekedniük. Ekkor az értéklánc-rendszer mindegyik tagja nyertes lehet, összefogással a termelékenységet növelve mindegyik résztvevő versenyelőnyhöz juthat. Az értéklánc-rendszerben jelentős költségcsökkentésre nyílnak lehetőségek, pl. tartós együttmüködés esetén csökkenthetök a tranzakciós költségek (a kapcsolattartás, informálódás, tárgyalás és szerződéskötés stb. költségei), a kockázatviselés költségei stb. Jelentős költségcsökkentés adódhat a kölcsönös informálásból, a tapasztalatok átadásából, pozitív externhatásokból stb. Pl. ha a vállalat segít a beszállítójának abban, hogyan csökkentse költségeit, ekkor a végtermék is olcsóbb lehet, ezáltal a vállalat költségelönye is javulhat. Az egymás rovására növelt versenyelőny viszont szétzilálja az értéklánc-rendszert. Az értékláncrendszerek kialakulása és stabilizálódása, a kölcsönös elönyök felismerése vezetett el a regionális klaszterek létrejöttéhez is. 


\section{Regionális specializáció}

Régóta közismert, hogy mind az abszolút, mind a komparatív elönyök befolyásolják a specializációt, milyen iparágban jöttek létre és maradnak fenn egy-egy országban, régióban a nemzetközi piacon is versenyképes vállalatok. A globális versenyben sincs egyetlen olyan ország, vagy régió, amelyik minden iparágban versenyezni tudna, ezért egy-egy ország és régió gazdasága olyan iparágakra, ágazatokra, iparági szegmensekre szakosodik, amelyekben a vállalatok relative termelékenyebbek, és az itt keletkező termékeket, szolgáltatásokat exportálják, míg az ország importál olyan javakat, amelyek elöállításában a helyi cégek kevésbé termelékenyek. A külföldön alapított vállalkozások közvetett módon szintén növelik az ország termelékenységét és exportképességét, mivel egyrészt kitelepítik a kevésbé termelékeny tevékenységeket, másrészt a szervizt, a termeléssel és a termékekkel járó szolgáltatásokat is odatelepítve a hazai cégek növelik az exportot és külföldről származó bevételeiket.

A regionális specializáció következtében a sikeres régiókban is csak néhány iparág tud megerösödni, a szükösen rendelkezésre álló termelési tényezök: képzett és kreatív munkaerö, a kutatási kapacitás stb. szükségszerúen koncentrálódnak. A specializáció általában öngerjesztố folyamattá válik, a domináns iparágak szükségleteinek megfelelően formálódnak az intézmények (oktató, kutató, tanácsadó stb.), erősödik meg a tapasztalaton alapuló tudásbázis (tacit knowledge). Pl. Seattleben öt iparág domináns (hajózás, fafeldolgozás, repülőgépgyártás, szoftverkészités, biotechnológia), Wales-ben újabban két iparág erősödött meg (autó-alkatrész, elektronika), Bázelben szintén kettő (bankügyek, gyógyszergyártás) stb.

A nemzetközi specializáció és a globalizáció jelenségei miatt a termelékenység jellemzőinek és a termelékenység növekedésének megértéséhez nem az egész gazdaságra kell koncentrálnunk, hanem csak a régióban müködó olyan speciális globális iparágakra és ágazati szegmensekre, amelyek versenyelönyökkel rendelkeznek. A tartós versenyelönyök általában egy-egy szük tevékenységi területre, a piac egy-egy szük szegmenséhez kapcsolódnak, amelyikre a régió gazdasága szakosodott.

\section{Innovációs kapacitás}

A vállalat versenyelönyeinek kialakulása és fenntarthatósága, azaz a tartós versenyelönyök alapvetően a széles értelemben vett innovációk folyamatos alkalmazásától függnek. A versenyelönyök tartósságának elemzésénél többféle általános szempontot kell figyelembe venni:

(a) A versenyelönyök forrásait hierarchiába rendezhetjük aszerint, hogy várhatóan milyen idötávra nyújtanak elönyöket:

- alacsonyrendü elönyök, pl. az olcsó nyersanyag, alacsony bérköltségek, széles körben alkalmazott (és sokak által elérhető) technológia és gépi 
eszközök stb., amelyeket könnyü utánozni, emiatt a versenytársakkal szembeni versenyelöny hamar megszünik,

- magasrendü elönyök, pl. az innovátorok, a differenciált termékek, egyedi minőségi szolgáltatások versenyelönyei stb., amely előnyök kihasználásához magasan képzett, specializált munkaerő szükséges (állandó tréningek, szakképzés stb.), folyamatos és kumulált befektetések (marketingbe, K+F-be), valamint magas kockázatviselési hajlandóság, ezeket az elönyöket a versenytársak közuil csak kevesen és lassan tudják mérsékelni.

(b) A versenyelönyöket nyújtó források száma is döntő, ha a vállalatnak csak egy tevékenységben van elónye, akkor a versenytársak hamar lenullázzák és felülmúlják ezt az előnyt, ezért az értéklánc több elemében törekedni kell versenyelőny kialakítására.

(c) A versenyelönyök tartóssága az innovációs készségtőll is függ, mivel a piaci igények is állandóan változnak, a versenytársak is próbálkoznak, ezért állandó késztetés és próbálkozás kell a versenyelőnyök fenntartására, erősítésére.

Az innovációs kapacitás támogatása nem korlátozódik a tudományos kutatásra, hanem a kutatás, innováció, oktatás és szakképzés egyidejü fejlesztését, a régióban a fejlett innovációs kultúra létrehozását tủzi ki célul. Ez az innovációs kulturális háttér egyre inkább koncentrálódik a létrejövő vállalati hálózatokban vagy klaszterekben, ösztönzi a kis- és középvállalkozások innovációit és biztosítja a tudományos eredmények széles körü elterjedését. A K+F támogatásának célja maximalizálni a tudományos és technológiai elönyök ,túlcsordulását”, elterjedését és megjelenését a gyártási folyamatokban, a vállalati versenyelőnyökben. Egy régióban az innovációs kapacitás három része (Porter 1999):

(a) Az innovációs alapinfrastruktúra: az oktatási rendszer (közép- és felsöfok), alapkutatásokat végzö intézmények, információs és kommunikációs infrastruktúra, kockázati tőketársaságok stb.

(b) A régió domináns iparágainak innovációs háttere: speciális iparági kutatóintézet és laboratóriumok kialakítása, speciális müszaki képzés (felsőfokú, PhD) támogatása, iparági információs adatbázisok létrehozása, iparági kiadványok és konferenciák támogatása stb.

(c) A kapcsolatok minősége az innovációs alapinfrastruktúra és az iparági speciális innovációs háttér elemei között.

Az előzőek alapján a régióban egyrészt fejleszteni szükséges az innovációs alapinfrastruktúrát, amely az innovációs kultúrát hosszabb távon erősíti, viszont nem nyújt vállalati versenyelönyöket, csak a versenyhátrányokat mérsékelheti. A régió domináns iparágainak versenyéhez szükséges speciális innovációs háttér fejlesztése javíthatja ezen iparágak versenyelőnyeit, a kapcsolatok minősége pedig elősegíti az iparág reagálását a bázisinnovációkra, és a régió esetleges szerkezetváltását is felgyorsíthatja. 


\section{Hazai és térségi bázis}

Az eltérő országokban müködő globális vállalatok különböző elvekből kïinduló, de egyaránt sikeres stratégiákat dolgoznak ki versenyelönyeik fenntartására, ezek a stratégiák a hazai bázis (home base) által nyújtott elönyökre épülnek. Egy globális vállalat hazai bázisa azon ország, ahol a vállalkozás alapvetö versenyelönyei keletkeznek (Porter 1990; Szentes 1998). Általában hazai bázis az olyan ország, amely a vállalat székhelyének (székházának) és vezető szakembereinek, kulcsrészlegeinek helyet ad, ahol a vállalat versenystratégiáját kidolgozó menedzsment tagjainak többsége él és dolgozik, ahol több esetben a törzstermékeket és az egyedi, igényes kivitelü, a cég „márkáját” jelzö termékeket gyártják, és ahol a lényegi technológia fejlesztése is általában zajlik. Egy globális vállalat hazai bázisa multiplikátor hatást fejt ki lokális/regionális környezetében és pozitiv externhatásokat jelent az itt müködö többi iparág és vállalat számára is, mivel mintát nyújt, a vállalati tudás szétterjed és ismertsége bizalmat vált ki a befektetök körében. Az is jellemzö, hogy a meghatározó, a vállalat versenystratégiáját befolyásoló tulajdonosok általában a hazai bázisban tömörülnek. A részlegeket, telephelyeket több országban fenntartó globális vállalat versenyelönyeinek nagy része egyetlen országban, a hazai bázisban keletkezik, ahol a közös nyelv, kultúra, közoktatás, tradíciók, gazdasági szabályozás stb. megkönnyiti a kommunikációt, együttmüködést.

A globalizáció korában az országok korábbi kiemelkedỏen fontos szerepe gyengül, a vállalatok nemzetközi versenyképességét, versenyelőnyeit egy nagyon lokalizált folyamat hozza létre és tartja fenn, a vizsgálatok szerint egy adott iparág sikeres vállalatai az országon belül földrajzilag is koncentrálódnak egy (esetleg néhány) városban, térségben. A fentiek miatt a hazai bázison, az országon belül bizonyos térségek egy adott iparág számára kiemelkedő fontosságúak. A hazai bázison belüli térségi bázis a globális vállalat azon földrajzilag koncentrált környezete, amely lokális környezetben versenyelönyei gyökereznek. Egy országon belül a térségi bázisban van a vállalat székhelye (székháza) és vezető szakembereinek, kulcsrészlegeinek lakó- és munkahelye, ott tömörülnek a versenyelőny kialakításában fontos intézmények (iparági kutatóintézetek, fejlesztö cégek, egyetemek, kapcsolódó vállalkozások stb.). A térségi bázis egy lokalizált agglomerációs gazdaságot ${ }^{10}$ jelent, amelyben a versenyelönyök keletkeznek, pl. a Szilícium-völgy a csúcstechnológiai (mikroelektronikai, biotechnológiai stb.), London a pénzügyi vállalkozások, Bázel a svájci gyógyszergyárak számára jelent térségi bázist.

A hazai bázis a belföldi piac és piaci szabályozás (pl. törvényhozás, adózás stb.), a közös kultúra (nyelv, tradíciók, fogyasztói szokások stb.) miatt alkot egységes hátteret, viszont a versenyelönyök többi része adott iparág esetén leszúkíthető valamilyen térségi bázisra, általában egy nagyvárosra és vonzáskörzetére. Egy régió gazdaságfejlesztésében döntő, hogy a régióban müködő nagyobb vállalatoknak térségi bázisa-e, azaz a vállalati döntési központok ott találhatók-e. A régió gazdasága kiszolgáltatott, ha nincsenek olyan iparágai, amelyeknek térségi bázisa ott mủködik. Nyilvánvalóan a regionális, térségi versenyképesség elemzésekor, az ezen alapuló 
gazdaságfejlesztési stratégia és programok kidolgozásakor kulcsfontosságú az adott iparág térségi bázisának meghatározása.

Porter fentiekben áttekintett föbb állításait összegezve a globális vállalatok versenyelönyei döntő módon a hazai bázis jellemzöitől, valamint a térségi bázis, így a régió, a város nyújtotta lehetőségektöl függnek, amire a vállalat versenystratégiáját alapozza és versenyelönyeit tartósitani tudja. A globális verseny lényegében az olyan régiók versenye, amely régiók a globális iparágak térségi bázisait alkotják. A térségi bázisban koncentrálódnak az adott iparág értéklánc-rendszerének legfontosabb elemei, többek között a versenyelőnyöket fenntartó innovációs kapacitás is. Több esetben az egyes iparágaknál pontosan kimutathatók azok a történelmi okok is, amelyekre visszavezethetők ezen elönyök kialakulásának és helyi kötődésének indítékai.

\section{A Porter-féle rombuszmodell}

A régió versenyképességének javítását visszavezettük a régióban mint térségi bázisban mủködő globális vállalatok termelékenységét, azaz tartós versenyelőnyeit befolyásoló tényezők kialakítására és támogatására. A rombuszmodell ezen tényezöket rendszerezi az alábbi, részben már emlitett alapfeltevésekböl kiindulva:

(a) A piaci verseny szerkezete és a versenyelönyök forrásai eltérőek az egyes iparágakban, azaz a régión belül iparáganként kell külön-külön megvizsgálni és elkülöníteni az elönyök forrásait.

(b) A globális vállalatok gyakran helyezik az értéklánc egyes tevékenységeit külföldre (illetve más régiókba), de a vállalat magasrendủ és tartós versenyelönyeit az iparág térségi bázisának jellemzöi alakítják (amit a tevékenységek széttelepítése alig befolyásol), mivel itt folynak a lényegi tevékenységek (core competencies) és itt születnek a stratégiai döntések.

(c) A globális vállalatok tartós versenyelönyüket megszerezni és fenntartani csak innovációk sorozatán keresztül képesek (nemcsak technológiai, hanem szervezeti, piaci stb. innovációkon keresztül), mivel a versenytársak is állandóan fejlesztenek, ezért a régió magas szintű és speciális innovációs kapacitása szükséges a vállalati versenyelőnyökhöz.

A Porter-féle rombuszmodell a régióban domináns iparágak tartós versenyelönyeit meghatározó mikroökonómiai üzleti környezet jellemzőit négy alapvető determinánsba csoportosítja (3. ábra). 


\section{3. ÁBRA}

A Porter-féle rombuszmodell: a mikroökonómiai üzleti környezet (Porter's Diamond Model: the Microeconomic Business Environment)

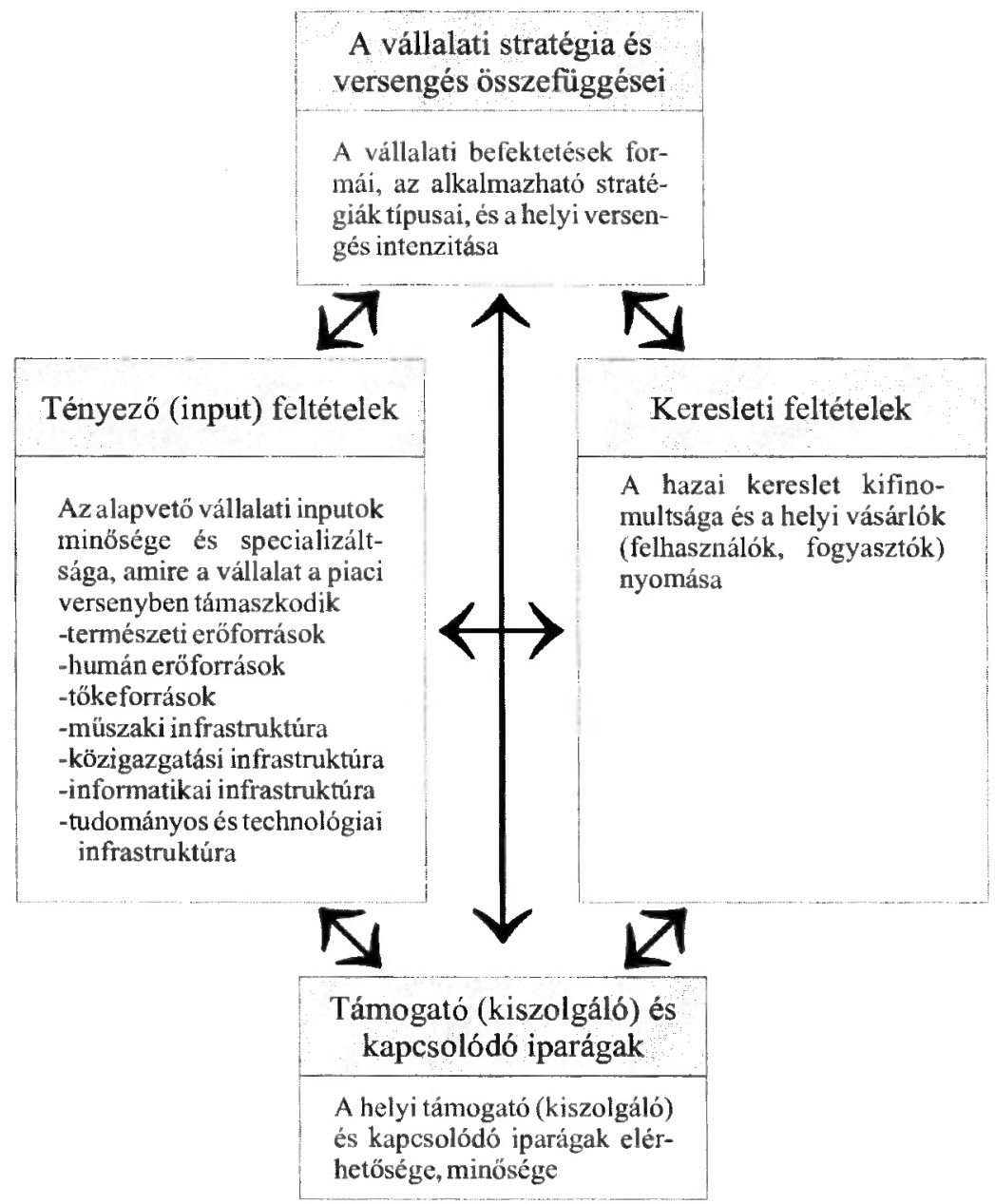

Forrás: Porter (1999, 31) alapjản saját szerkesztés.

A modell nem elszigetelt, hanem egymást kölcsönösen erősítő, egymásra ható, egymással kapcsolatban levö determinánsokból áll. A régió azokban az iparágakban a legsikeresebb, a rombusz ott a legkedvezőbb, ahol mind a négy determináns hozzájárul az iparág magasrendú versenyelỏnyeihez. Egy vagy két determinánson alapuló versenyelöny előfordul a természeti erőforrásoktól függő, a kevésbé igényes technológiájú, vagy alacsony szakképzettséget igénylö iparágakban is, de ezek az alacsonyrendú elönyök általában nem tartósak. A rombuszmodell újabb, módosított változatát ismertetjük, áttekintve az itthon kevéssé ismert fogalmakat és csoportosításokat Porter két alapvető könyvére támaszkodva (Porter 1990; 1998a). 


\section{Tényezö (input) feltételek}

A termelési tényezök, a helyben levő, a vállalatok által kevésbé befolyásolható, „készen talált" inputok fontos szerepet töltenek be a versenyelőnyök kialakulásában. Azonban szerepüket sokszor túlhangsúlyozzák, mivel időnként a hiányuk serkent innovációra és hatékony versenystratégia kialakítására. Manapság az országok, régiók elöállítják a legfontosabb termelési tényezőket: a képzett munkaerőt és az innovációs kapacitást, nem pedig „öröklik”. A tényezö-ellátottsághoz kötődő gondolatok a fejlődő és az átmeneti országokban fontos szempontokat vetnek fel, Magyarországon is a hálózati infrastruktúra térbeli kiépítése prioritást élvez. A hagyományos termelési tényezök (természeti eröforrások, munka, töke, vállalkozói készség) túl általánosak a vállalati stratégiák kialakításához, ezért másfajta csoportosítást célszerủ alapul venni az iparágak tényezőellátottságának vizsgálatához. Két csoportra oszthatók az input tényezöi: erőforrásokra és infrastruktúrára.

Az eröforrások, inputok, amelyek a termelési tényezőket " jelentik:

(a) Természeti eröforrások: a természeti erőforrások bősége, minösége, elérhetősége, a termöföldek, a víz ára, a vízenergia, a klimatikus viszonyok, a földrajzi elhelyezkedés (benne az időzóna) stb.

(b) Humán erôforrások: a régió humán erőforrásainak mennyisége, szakképzettsége (szakértelme), a bérek színvonala (benne a menedzsereké is) stb. A humán erőforrás számtalan apró tényezőre bontható, amit a speciális iparágak esetében egyedileg kell mérlegelni.

(c) Töke (pénzügyi) források: az iparágak finanszírozására rendelkezésre álló töke összege és költsége, ez a tőke nem homogén, hanem kötvényekböl, kockázati tőkéből, részvényekből stb. áll. A tőketömeg nemcsak az ország lakosságának megtakarítási hajlandóságától és a nemzeti tôkepiac szerkezetétöl függ, mivel a globalizáció egyre inkább lehetővé teszi a nemzetközi tókeáramlást.

A tényezök másik csoportja, az infrastruktúra az eladók és a vevők közötti kapcsolatokat biztosító létesítmények összessége. Porter a globális vállalati versenyelönyök szempontjából az infrastruktúra újszerü csoportosítását javasolja (Porter 1998a, 325):

(a) Müszaki infrastruktúra: a versenyben felhasználható müszaki infrastruktúra költsége (ára), típusa, mennyisége, mint a közlekedési hálózat, hírközlési rendszer, posta és csomagküldő szolgálatok, fizetési átutalások, az egészségügyi rendszer, a lakásállomány és kulturális intézmények stb.

(b) Közigazgatási (adminisztrációs) infrastruktúra: a központi jogszabályok, helyi rendeletek elősegítik-e a vállalati versenyelönyök fenntartását, avagy gátolják, ezeket az előirásokat betartják-e, továbbá a központi és helyi intézmények kiépültsége, müködésük hatékonysága.

(c) Informatikai infrastruktúra: napjainkban az informatikai hálózatok kiépültsége, az adat- és információ továbbítás gyorsasága és megbízhatósága, az 
adatbázisok elérhetősége (Internet) alapvetö, mivel hiányuk komoly versenyhátrányt jelent.

(d) Tudományos és technológiai infrastruktúra: a tudományos, technikai és üzleti (piaci) ismeretek, amelyek a termékek elöállításához és a szolgáltatásokhoz kellenek. Ez a tudásszint felhalmozódott az egyetemeken, állami kutatóintézetekben, magán (üzleti) kutatási lehetőségekben, adatgyüjtő (statisztikai) ügynökségekben, gazdasági (kereskedelmi) kamarákban, az üzleti és tudományos irodalomban, üzleti jelentésekben stb.

A tényezőellátottságot nem általánosságban kell figyelembe venni, hanem csak azt az elemét és olyan mértékben, amennyiben ez a tényező szükséges a konkrét iparág versenyelönyének kialakulásához, amelyik tényezőt inputként felhasználja ez az iparág (pl. a szoftverfejlesztéshez programozókra van szükség és nem agrármérnökökre). A vállalati versenyelöny nem a tényezők mennyiségétől függ, hanem minőségétöl és attól, hogy mennyire hatékonyan, milyen módon használják fel a rendelkezésre álló tényezőket. A termelési tényezők egy része helyettesíthetö (pl. a munkaerö helyettesíthető gépekkel, azaz tőkebefektetéssel), valamint mobilizálhatóak, a régiók és országok között áramolhatnak. Alapkérdés, hogy a vizsgált iparág versenyelönyéhez szükséges tényező a régióban mint térségi bázisban rendelkezésre áll-e, milyen költséggel használható fel, ha pedig nincs a régióban, akkor megéri-e a létrehozása (odaszállítása), avagy helyettesítése más tényezőkkel.

A termelési tényezök versenyelönyökre gyakorolt hatásának elemzéséhez a tényezőket kétféle szempont, szűkösségük és specialitásuk alapján csoportosítjuk:

(a) Szükösségük, fejlesztésük lehetségessége és idöigénye szerint alaptényezőket és fejlett tényezőket különböztethetünk meg:

- Alaptényezök: természeti erőforrások, időjárás, földrajzi elhelyezkedés, képzetlen és betanított munkaerö, alapvető müszaki infrastruktúra, állóeszközök (építmények, berendezések) stb.

- Fejlett tényezök: modern kommunikációs infrastruktúra, magasan képzett munkaerö (mérnökök, informatikusok), egyetemi kutatóintézetek a legújabb kutatási területeken stb.

Az alaptényezök „örököltek”, kevésbé igényes magán vagy állami befektetés szükséges a kiaknázásukra, az országok és régiók többségében szinte mindenütt rendelkezésre állnak, ezért csak kevés iparág esetében jelentenek versenyelönyt: fontosak a kitermelö iparágakban (bányászat), az erdő- és mezögazdaságban (fakitermelés, speciális növénytermesztés stb.), a helyi igényeket kielégitő építőanyagés épitőiparban (lakás-, iskolaépítés stb.). Az alaptényezők az olyan iparágakban lényegesek, ahol a technológiai és képzettségi szükségletek szerények és a technológia (az eszközök és a know-how) széles körben elérhetö (ismert), ahol a menedzselés és a mérnöki munka rutinszerü. Az alaptényezőkre vezethetö vissza a legtöbb iparágban a vállalatokon belüli telephelyek létrehozása, az értékláncok azon tevékenységeinek kitelepítése a hazai bázisból, ahol a költségelőny a döntő (ezáltal minimalizálják a költségeket). Az alaptényezök széles körben hozzáférhetők, ezért 
a piaci versenyben háttérbe szorulnak és az iparágak többségében nem adnak magyarázatot a versenyelönyök kialakulására, ezáltal a régió versenyképességére.

A fejlett tényezők szükösen állnak rendelkezésre, mivel fejlesztési igényük nagy és folyamatos befektetéseket igényelnek mind az emberi, mind a fizikai tókébe. A fejlett tényezőket nehéz beszerezni a világpiacon, nem mobilak, hanem helyhez kötöttek, emiatt nehéz „utánozni” öket. Általában egy integrált folyamat során jönnek létre, mint az innovációs kapacitás részei, fejlesztésük kapcsolódik a vállalatok átfogó versenystratégiájához és legjobb térbeli elhelyezésüknek a térségi bázis ad otthont. Az innovációs kapacitás részeként több esetben egyedi tényezőkről van szó (néha egy-egy kiemelkedő szabadalomról), amelyek kötődnek egy-egy innováció kifejlesztéséhez, valamelyik iparág fejlesztési problémájának megoldásához. Fejlett tényezők szükségesek a magasrendü versenyelönyök eléréséhez, mint pl. a differenciált termékek gyártásához és a technológia kifejlesztéséhez. A fejlett tényezők nyilvánvalóan az alaptényezőkre épülnek, több iparágban vissza is hatnak rájuk (pl. a mezőgazdaság versenyelönyeinek fenntartása speciális biológiai kutatások nélkül nehezen képzelhetö el).

(b) Specifikumaik alapján általános és speciális tényezők csoportjait különböztethetjük meg:

- Altalános tényezők: az iparágak széles körében a versenyelönyökhöz szükséges tényezők: autópálya rendszer, hírközlés, föiskolai végzettségú motivált munkaerő stb.

- Speciális tényezők, egy-egy iparág versenyelönyeihez szükséges tényezők: speciális szakképzést nyújtó intézmények, egyedi infrastrukturális létesítmények, speciális ismeretekkel bíró $\mathrm{K}+\mathrm{F}$ intézmények, iparági témákra specializálódott tudományos kutatók és fejlesztôk stb.

Az iparágak magasrendü versenyelónyéhez a specializált tényezök nyújtanak lényeges és folyamatos hátteret, az általános tényezők csak az alacsonyrendủ elönyöket támogatják. Megfigyelhetö, hogy az általános tényezöktöl függö tevékenységek gyorsan el tudják hagyni a hazai bázist, mivel több esetben máshol is megfelelö, de olcsóbb telephelyek vannak. A speciális tényezők általában az általános tényezökre épülnek, pl. az adott iparág fejlesztéseihez szükséges speciális mủszaki $\mathrm{PhD}$. képzés az általános egyetemi oktatásra. $\mathrm{Az}$ is jellemzö, hogy a mai specializált tényezők egy része holnapra általánossá válik. A specializált tényezök gyakran kockázatos, koncentrált magán és társadalmi befektetéseket igényelnek. A régiók versenyképességét a hazai bázisban az általános és speciális tényezök elérhetősége és minősége határozza meg, az olyan általános és speciális tényezők együttese, amelyek a régió domináns iparágaiban a tartós vállalati versenyelönyökhöz szükségesek.

A termelési tényezők egy része örökölt, független a vállalatok döntéseitöl, másik része gyarapítható, létrehozható a régió fejlesztése során. A magasrendú versenyelönyök döntő része specializált tényezőkön alapszik, amelyek létrehozásához folyamatos befektetésre és megújuló programokra van szükség (szakképzés, $\mathrm{K}+\mathrm{F}$ ). Nincs olyan ország, amelyik a tényezők széles körét egyidejüleg képes lenne fejleszteni, ezért az országoknak, méginkább a régióknak specializált fejlesztéseket 
kell végrehajtaniuk. Alapvetőek azok az intézményi mechanizmusok, amelyek ezeket a speciális tényezőket létrehozzák: a közösségi és magán oktatási intézményeket, a szakképzést és továbbképzést, az állami és magán kutató- és fejlesztő intézeteket, a domináns iparágak fejlődéséhez szükséges speciális infrastruktúrát (pl. repülöteret, logisztikai központot stb.). A régiók gazdaságfejlesztésénél alapelv, hogy azt kell fejleszteni, amitől a régióbeli iparágak versenyelőnye tartósan fennmarad és nem azt, amit szeretnénk vagy meg tudunk valósítani.

A specializált és fejlett tényezők kialakításában az intézményi mechanizmusok akkor hatékonyak, ha ezekben a mechanizmusokban meghatározó a magán szektor szerepe, mivel a magánvállalatok vannak tisztában azzal, hogy milyen tényezök szükségesek az ő versenyelönyük fenntartásához. Az állami beruházások gyakran az alap- és általános tényezőkre koncentrálnak, a települési önkormányzatok pedig meglevő intézményeik érdekei szerint fejlesztenek (pl. a képzési intézményekben), nem pedig a vállalati versenyelönyök szükségletei szerint. A magán szektor azért is fontos, mivel az állami (önkormányzati) döntéshozatal lassú, a politikai és intézményi döntéshozók nem ismerik a különbözö cégek igényeit és nem tudják meghatározni azokat a kulcstényezőket, új innovációkat sem, amelyek a jövendö vállalati versenyelőnyökhöz szükségesek.

A tényezök hiánya miatt kialakult hátrányos helyzet megfelelö döntéshozatali mechanizmus során adott kedvezö válasszal több esetben előnnyé változtatható (a későn jövők elönye). A lényeg, hogy olyan versenystratégiát kell kialakítani, innovációkkal olyan megoldásokat alkalmazni, hogy a tényező hiánya (pl. Japánban a hazai energia és a nyersanyagok hiánya) vagy magas költsége (pl. Németországban a munkaeröé) ne okozzon versenyhátrányokat. A tényezök hiányára vagy költségességére adott vállalati válaszok csak akkor lehetnek sikeresek (pl. a just-in-time rendszer bevezetése Japánban, amely egyúttal a szükösen rendelkezésre álló és ezért magas bérletủ raktárakat is megszüntette, avagy magas munkabérek esetén a képzetlen munkaerő kiváltása automatizálással), ha a térségi bázisban párosulnak az általános és alaptényezök fejlesztésével.

Összegezve, az alap- és általános tényezők magas szintje szükséges, de nem elégséges feltétele a vállalati versenyelőnyök kialakulásához és fenntartásához, amelyek döntően az iparági verseny sikerességéhez nélkülözhetetlen fejlett és specializált tényezökre épülnek. Az általános tényezök csökkenthetik a vállalatok versenyhátrányait (pl. autópálya, felsőoktatás, telefonhálózat stb.), de csak a speciális tényezök hoznak létre versenyelőnyöket. Annak a kérdésnek sincs értelme, hogy egy régióban mennyire fejlett az infrastruktúra, avagy egy-egy részterületén hány \%-át teszi ki az országos átlagnak. A lényeges kérdés: a régióban müködő meghatározó iparágak tartós, azaz magasrendü versenyelönyéhez elégségesek-e a fejlett és speciális infrastruktúra elemei? Ha nem, akkor a regionális gazdaságfejlesztési stratégiában támogatni kell ezeknek a fejlett és speciális tényezöknek a kialakítását. 


\section{Keresleti feltételek}

A rombuszmodell második legfontosabb determinánsa az iparágak termékei, szolgáltatásai iránt megnyilvánuló hazai (belföldi) keresleti feltételek ${ }^{12}$. A hazai keresletnek elsösorban nem a mennyisége (nem az összkereslet értéke), hanem a minősége döntő. „A hazai kereslet összetétele a gyökere egy nemzet kompetitiv elönyének, míg a hazai kereslet nagysága és növekedési üteme csak módosítja ezeket az előnyöket a befektetöi magatartás által" (Porter 1990). Az iparágak versenyelőnyeinek kialakulásában a hazai kereslet három tényezőjét kell kiemelni: a hazai kereslet szerkezetét, növekedésének összetételét és ütemét, valamint azt a mechanizmust, ahogyan a hazai preferenciákat (azaz a termékek iránti igényt) át lehet transzformálni a külföldi piacokra (felkelteni a külföldi fogyasztók igényét ezen termékek iránt).

(a) A hazai kereslet összetétele: azokban az iparágakban és ipari szegmensekben jutnak a vállalatok versenyelónyhöz, ahol a hazai fogyasztói igények jelzik elöre a fogyasztási szokások várható változását, ahol a hazai kereslet szerkezete a vállalatokat versenyre és innovációra készteti. A globalizáció korában sem csökken a hazai (belföldi és helyi) kereslet szerepe, egyrészt a hazai vállalatok kisebb költséggel tudják felmérni a belföldi igények változását, hamarabb észlelik és pontosabban megértik, mint a külföldi vetélytársak, másrészt a külföldi vásárlók igényeinek változását jóval nehezebben lehet követni. A hazai és térségi bázis azért fontos, mivel ott élnek a menedzserek, a fejlesztök, a marketingesek stb., akik észlelik a piaci igények változásait és elökészítik a vállalati döntéseket. A hazai kereslet összetétele, szerkezete fontos szerepet tölt be a versenyelönyök kialakulásában:

- A hazai kereslet szerkezetének szegmentáltsága: ha az egyik piaci szegmensben jelentős a hazai igény, akkor az adott iparág a méretgazdaságosságot kihasználva versenyelönyre tud szert tenni, könnyebben tud betörni a világpiacra, illetve a tanulás (fejlesztés) fajlagos költsége is csökkenthetö.

- A kifinomult izlésü és igényes vásárlók: ezek a hazai vásárlók nyomást gyakorolnak az iparágra, hogy egyedi és magas minöségü termékeket állítsanak elö, ezáltal termékdifferenciálásra nyílik lehetöség. A kifinomult ízlésủ vásárlók igényeinek változását a fizikai (földrajzi) és kulturális közelség miatt először a hazai bázison (helyben) lehet érzékelni, ezáltal korán el lehet kezdeni a felkészülést az új igények kielégítésére (pl. legfontosabb kifinomult ízlésü vásárlók a helyben múködő csúcstechnológiai vállalkozások). Kis országok vállalatai is azokban a piaci szegmensekben tudnak versenyelönyökre szert tenni, ahol a hazai fogyasztók igényesek, emiatt előre jelezhetők a globális trendek (pl. Svájc, Hollandia, Svédország stb.).

- A fogyasztói szükségletek elörejelzése: az elöbbiekkel összhangban, ha a hazai igények változása elöre látható, akkor a vállalatok időben fel tudnak készuilni kielégítésükre a nemzetközi versenyben is. 
(b) A hazai kereslet növekedésének nagysága és alakulása: a hazai vállalatok által jól ismert hazai kereslet növekedése javítja a méretgazdaságosságból adódó versenyelönyöket. A javuló termelékenység általában új innovációk kifejlesztését is ösztönzi. Az egyedi iparági sajátosságoktól függ, hogy a korlátozott hazai piac mennyiben serkent az exportra.

- A hazai kereslet nagysága: azokban az iparágakban, ahol a méretgazdaságosság döntö, ott a jelentös méretủ hazai piacon dúló erös verseny a termelékenység növelésére, technológiai fejlesztésre, folyamatos beruházásokra ösztönöz. Föleg a kutatásigényes iparágakban döntő a hazai kereslet mérete, mivel a nagy bizonytalanság (a kockázat) miatt csak elegendỏ számú potenciális vásárló esetén érdemes kísérletezni.

- A független vásárlók száma: ahol csak egy-két vásárló van (monopszónia vagy duopszónia esetén), ott helyzetükkel visszaélve a vásárlók több esetben nem teszik lehetövé a versenyelöny érvényesítését. Ott van késztetés a versenyelőny kialakítására, innovációk kidolgozására, ahol sok a független vásárló, egyrészt sokféle piaci impulzust adnak, másrészt ekkor várhatóan több cég lép az iparág piacára és erősödik a verseny is.

- A hazai kereslet növekedési üteme: a növekedési ütem fontosabb, mint a kereslet abszolút nagysága, mivel növekedés esetén bizakodók az elörejelzések, élénkek a várakozások, érdemesnek tủnik beruházni, új technológiát alkalmazni.

- A hazai kereslet korai megjelenése: ha a hazai kereslet korábban fut fel, mint külföldön, akkor a hazai cégek lépéselőnybe kerülnek (amennyiben jelen vannak a hazai piacon), létrehozhatják gyártási feltételeiket és tapasztalatokat gyüjthetnek, azaz versenyelönyre tehetnek szert (pl. az USAban az Internet alkalmazása).

- A hazai kereslet korai telitödése: a hazai kereslet telítődésekor a vállalatok megpróbálnak külföldön terjeszkedni, ami javíthatja fajlagos költségeiket. A telítődött hazai piacon árverseny indul el, lemennek az árak, ami egyrészt élénkíti általában a keresletet (föleg a fogyasztási cikkeknél), másrészt az innovációkra kényszerülö cégek javítják a termékek minőségét és exportra is kényszerülhetnek.

(c) A belföldi kereslet nemzetközivé tétele: nem lehet egy iparág tartósan sikeres nemzetközileg, ha otthon alig fogyasztják termékeit (szolgáltatásait), mivel a hazai presztízs, hírnév, elismertség stb. kell ahhoz, hogy a legjobb képességü fiatalok ebbe az iparágba menjenek dolgozni, az egyetemek odafigyeljenek az utánpótlásra és az iparág témáival foglalkozzanak kutatásaikban, az állami és önkormányzati infrastrukturális fejlesztések ezen iparág speciális igényei szerint alakuljanak stb. Azaz hazai bázis nélkül a nemzetközi versenyben hosszabb távon nem lehet megőrizni a versenyelönyöket, kivéve a természeti erőforrásokra alapozódó néhány iparágban. Viszont szükös hazai piac esetén a belföldi szükségletek transzformálásával a globális igények kialakíthatók és növelhetök, amelynek föbb módjai: 
- Mobil vagy többnemzetiségü helyi vásárlók: ha a termék vásárlói mobilak, azaz külföldröl idejönnek vásárolni, avagy nemzetközi vállalatok, akkor ez versenyelönyt jelent, mivel a külföldi piacon történő megjelenés költségei megtakaríthatók (föleg a szállításigényes iparágakban), ilyen pl. a turizmus és kapcsolódó tevékenységei (szállodák, autókölcsönzök, éttermek stb.), főleg a bevásárló-turizmus.

- A külföldi igények befolyásolása: szintén versenyelönyt jelent a hazai fogyasztási szokások elterjesztése külföldön, ezáltal ösztönzik a hazai cégek exporttermékeinek vásárlását. Eszközei változatosak: tréningek, továbbképzések szervezése a befolyásos szakértők részére (pl. orvosok tömeges továbbképzése az USA-ban fellendítette az amerikai orvosi berendezések exportját), nemzetközi összejövetelek rendezése, tudományos kommunikáció a befolyásos, sokak által olvasott szaklapokban, a fogyasztási minták terjesztése (filmekben, televíziós sorozatokban stb.), a tömegturizmus fellendülése, ezáltal a hazai turisták külföldön is a hazai cégek megszokott szolgáltatásait várják el (pl. amerikai turisták a Hiltont, a McDonalds-t stb.). Pl. könnyebb azokat a külföldi rétegeket megcélozni az export során magyar élelmiszerekkel (pl. borokkal) is, akik turistaként megismerték és megkedvelték őket.

A különböző hazai keresleti feltételek természetesen felerösítik egymást, hatásaik nem elkülönülten, hanem összegzödve jelentkeznek és kiemelkedö fontosságúak a vállalatok versenyelönyei szempontjából. A vállalatok hazai bázisának, azaz a belföldi és helyi keresletnek a szerepe döntö, mivel az ott keletkező piaci impulzusok jutnak el leggyorsabban a vállalat versenystratégiáját kidolgozókhoz és a döntéshozókhoz. Az igényes hazai keresletre adott helyes válasz miatt vált nemzetközileg versenyképessé pl. a dán környezeti ipar (a szigorú hazai környezeti szabványok miatt), az olasz csempeipar, a japán híradástechnika stb.

\section{Támogató és kapcsolódó iparágak}

A rombuszmodell harmadik determinánsa az iparág versenyelönyét az inputokat szolgáltató többi iparágra vezeti vissza. Megfigyelhetö, hogy egy nemzetközileg sikeres iparág mögött szintén sikeres partnerek állnak, akik az inputokat és egyéb szolgáltatásokat nyújtják. Másképpen fogalmazva, egy vállalatnak akkor vannak tartós versenyelőnyei, ha értéklánc-rendszerének tagjai is sikeresek. Az adott vállalat értéklánc-rendszerébe tartozó vállalatokat, amelyekkel valamilyen szintü üzleti kapcsolatban áll, két nagyobb csoportra osztjuk a kapcsolat intenzitása szerint:

(a) Támogató (kiszolgáló) iparágak: az adott vállalatnak azok a partnerei, akiktöl inputját: állóeszközeit, fogyóeszközeit, alapanyagait vásárolja, a szolgáltatásokat igénybe veszi (bankszolgáltatások, szállítás, informatika stb.). Nyilvánvalóan a vállalat attól vásárolja inputját, aki azt minőségben, árban, megbízhatóságban stb. a legjobb feltételekkel szállítja. De a hazai bázisban működö, nemzetközileg sikeres támogató iparágak általában versenyelönyöket jelente- 
nek az adott iparág számára (pl. a szállítás és kapcsolattartás olcsóbb és gyorsabb), több esetben még a piacra kerülés előtt megismerhetök az új, innovatív eszközök, kedvezménnyel megszerezhetők az inputok a hosszabb távú, stabil és ellenőrizhető kapcsolatok miatt stb., azaz egyféle „nem versenytársak közötti" lokális szövetség jöhet létre. A személyes kapcsolatok kiépülésével a vállalkozók üzleti tapasztalataikat és egyéb információikat is kicserélik, gyors és állandó kommunikáció jöhet létre, hajlandók a kölcsönösen elönyös együttműködésre, söt kölcsönösen befektetnek egymás vállalkozásaiba (kereszttulajdonlás). Pl. az olasz ékszerek nemzetközi sikerei az olasz ékszerkészítö-gépek sikerét vonta maga után, az olasz csempék sikere az olasz égetökemencék exportját, a japán autóipar nyomában pedig a nyolcvanas években a japán robotgyártók is kiléptek a nemzetközi piacra stb.

$\mathrm{Az}$ alacsonyrendủ elönyöket kihasználó vállalatoknál a hazai bázisban levö támogató iparágak szerepe kevésbé fontos (kivéve olyan eseteket, amikor a szállítási költség jelentős). A magasrendủ előnyökre törekvő, az innovációk alkalmazásaira épülő vállalatoknál lényeges azonban a helyben, a térségi bázisban levő támogató iparágak jelenléte, az ehhez kapcsolódó üzleti klíma és innovációs miliő. A támogató iparágak nem versenytársai a támogatott iparágnak, ezért általában hajlandók tapasztalataik átadására, így a közelségből adódó szinergia a gyorsaságban, a rugalmasságban is megjelenik, a kockázat mérsékelhető. Továbbá a támogató iparágban véghezvitt innováció segíti a támogatott iparág versenyelönyeinek fenntartását is. Mivel az inputok külföldröl is, illetve bárhonnan beszerezhetök, ezért a hazai bázisból csak a nemzetközileg sikeres támogató iparágak jöhetnek szóba, mint együttmüködö partnerek. Az is megfigyelhetö, hogy nem automatikus a térségi bázison belüli együttmủködés, a támogató iparágakat sok esetben előszeretettel választják más országokból, ezért a régió versenyképességének erősítése érdekében ki kell alakítani a vállalatok közötti lehetséges együttmüködést elöidézö mechanizmusokat. Jellemző az is, hogy kitelepítik külföldre azokat a támogató iparágakat, amelyekben lassú a megtérülés és gyenge a versenyelöny, ahol nincs szükség innovációra, ezáltal a szúkös helyi erőforrások (tőke, szakképzett munkaerö) az innovativ ágazatokba áramolhatnak.

(b) Kapcsolódó iparágak: az adott iparággal üzleti kapcsolatban nem álló azon iparágak, amelyekben a vállalatok képesek megosztani vagy koordinálni a tevékenységeket az értéklánc-rendszerben (pl. egymással nem versenyző alkatrész-beszállítók: mủanyagipari és fémipari cégek), illetve azok a cégek, amelyek termékei kiegészítik egymást (pl. számítógépgyártás és irodai bútorkészítés). A lényeg, hogy ezek az iparágak más-más termékpiacon versenyeznek, azaz nem egymás versenytársai, viszont egyeztetve egymást tudják erösíteni. A tevékenységek megosztása lehet a technológia fejlesztésében, a gyártásban, az elosztásban (kereskedelemben), a marketingben, a versenystratégiák részbeni egyeztetésében, az információcserében (technikai ismeretek cseréje) stb. A térségi bázisban müködő kapcsolódó iparágak a közelségből adódó kisebb 
tranzakciós költségek, a gyorsabb információáramlásból eredő rugalmasság, a napi kapcsolatokból eredó bizalom miatt elönyt élveznek. Jellemző, hogy a hazai bázis kis- és középvállalatai között erös a verseny: a biztosnak tünö megrendelésekre és a nagyvállalattal történö együttmüködésre sokan pályáznak. Megfigyelhető, hogy egy iparág nemzetközi sikere képes pár év múlva a kapcsolódó iparágak sikerét is elöidézni, tipikus példa Olaszországban a szobabútorgyártás és a lámpagyártás (világítótest), avagy Németországban a konyhai bútorgyártás és a háztartási gépek, Japánban a fényképezőgépek és a fénymásolók elöállítása.

Egy vizsgált iparág tevékenységét számtalan más iparág müködése, termékei és tevékenysége is befolyásolják. A gyakorlatban nehéz határvonalat húzni a támogató és kapcsolódó iparágak között, részben a szerteágazó vállalati tevékenységek miatt, részben a kapcsolatok gyors változása következtében. Nyilvánvalóan időben gyorsan változik az üzleti partnerek köre, támogató iparágból versenytárs, avagy kapcsolódó is lehet, illetve fordítva is. A földrajzilag koncentrálódó támogató és kapcsolódó iparágak ún. regionális klasztert alkothatnak, amelyre késöbb röviden kitérünk.

\section{A vállalati stratégia és verseny összefüggései}

A nemzetek, régiók versenyképessége azokon a globális vállalatokon keresztül jelenik meg, amelyek hazai, vagy térségi bázisa az adott országban, régióban található. Döntő, hogy ezek a vállalatok hogyan jönnek létre, szerveződnek meg, miképpen alakítják ki céljaikat és versenystratégiájukat ${ }^{13}$, milyen irányítási rendszert alkalmaznak stb. A vállalati stratégiák, a vállalatok szervezetei nemzetenként eltérhetnek a kulturális tradíciók, magatartásminták, az adott ország versenyszabályozása stb. következtében:

(a) A belföldi vállalatok stratégiája és szerkezete: nincs mindenütt érvényes általános vállalati stratégia és szerkezet, a vállalatok tỏbbféle stratégiával és szervezeti megoldással lehetnek sikeresek, döntő, hogy a nemzeti jellemzőkhöz igazodjon a vezetési és szervezeti struktúra (pl. a Harmadik Olaszországban a kis- és közepes cégek, Németországban a müszaki végzettségủ menedzsment által irányított nagyvállalatok dominánsak). Jelentős nemzeti különbségek figyelhetők meg a vezetési gyakorlatban (csapatmunka vagy hierarchia), az egyéni feladatok mélységében, a dỏntési folyamatok eszközeiben, a vásárlókkal való kapcsolattartásban stb. A nemzetközi versenyelönyök kialakítását a nyelvtudás és a nyelvtanulási készség, valamint a globális piacra való kilépést a sikeres iparágakat támogató nemzeti gazdaságpolitika elősegítheti.

(b) Célok: a nemzetek között, nemzeteken belül és a vállalatok körében is éles különbségek figyelhetők meg a kitüzött célokat tekintve, valamint abban, hogyan próbálják motiválni a menedzsereket és foglalkoztatottakat e célok elérésére:

- A vállalatok céljai: a fó célokat a tulajdonosi struktúra határozza meg, a részvényesek motivációi, a vállalatirányítás felépítése, a felső vezetők mo- 
tivációi és érdekeltsége. Eltérő nemzetenként a tőkepiac szerkezete, a bankok tulajdonosi jogosítványai, az intézményi befektetők szerepe stb., így a vállalatok céljainak kitủzésében a nemzeti sajátosságok kerülnek elötérbe.

- Az egyének céljai: a különböző iparágak sikere az ott dolgozó egyének erőfeszítésein múlik, a menedzserek és foglalkoztatottak mennyiben motiváltak az együttmüködésben, saját tudásuk (ismereteik) fejlesztésében, képességeik kifejtésében stb. Az egyéni motivációt leginkább a jutalmazási rendszer (fizetés, egyéb juttatások, bónusz stb.), az elörejutási rendszer, a foglalkoztatottak és a vezetés közötti kapcsolat-rendszer befolyásolja, de az adott ország adózási rendszere és a megtakarítási (vagyongyüjtési) szokások, a sikeresség és bukás társadalmi megítélése, az iparági „büszkeség” és társadalmi elismertség stb. is elötérben állnak.

- A nemzeti presztizs/prioritás hatása a célokra: a különböző iparágakhoz vonzódó munkaerő minőségére, az egyének motivációjára hatással van a nemzeti (társadalmi) prioritás, az iparág státusza, elismertsége. A versenyelöny sokszor az oktatási rendszertől függ, a legtehetségesebb fiatalok milyen képzettséget, melyik iparágban hasznosítható tudást szereznek, a jövedelemtől függetlenül milyen foglalkozásra ,néznek fel”, avagy mit „néznek le".

- A tartós elkötelezettség fontossága: az iparág, a „szakma” iránti elkötelezettség mind a tulajdonosok, mind a munkaerö (menedzserek, foglalkoztatottak) részéröl elengedhetetlen a versenyelönyök fenntartásához. Az eröforrások (tőke, munkaerö) iparágak közötti mobilitása a gyakorlatban lassú, mivel az elkötelezett munkaerö erőfeszitései az innovációk révén nagyobb mértékben javíthatják az iparági termelékenységet, mint az erőforrások újraallokálásával.

(c) A belföldi (hazai) versengés: a vállalati versenyelönyök az erös belföldi iparágon belüli versenyből erednek, azokban az iparágakban sikeresek az országok, ahol erős és többszereplös a belföldi piac. Az erős belföldi verseny készteti a vállalatokat az innovációra, a fejlesztésekre és a nemzetközi piacra történő kilépésre, az exportra, így szük belföldi piac esetén sem lép fel méretgazdaságossági probléma (pl. a svéd kamiongyártás: Volvo, Saab-Scania, vagy a svájci gyógyszergyártás). A belföldi verseny sokszor nem árversenyt jelent (pl. a német autópiacon), hanem termékdifferenciálást, a technológia fejlesztését, a szolgáltatásokat, a megjelenést stb. Míg egy zárt gazdaságban versenyképesek lehetnek a monopóliumok is, addig egy nyitott, globális gazdaságban a versenykörnyezetböl jövő cégekkel szemben elveszítik pozicióikat.

A belföldi versengés az egész nemzetgazdaság számára versenyelőnyöket képes generálni, mivel bármely iparág számára hasznos tapasztalatokat, mintákat, eljárásokat stb. mutat fel, a tapasztalatok megjelennek az oktatásban (egyetemeken) és szétterjednek az egész országban, azaz egy nemzetközileg sikeres iparág pozitív externhatást nyújt a többi iparág számára is. Az iparágban müködő cégek sokszor 
egy-egy városban koncentrálódnak, ekkor az agglomerációs hatások erösek, a városban kiépülnek a speciális iparági intézmények: speciális fejlesztö intézetek, egyetemi szakok, reklámcégek, tanácsadó cégek, erősödnek a nemzetközi szakmai kapcsolatok stb. A belföldi piacon nemcsak a nagyvállalatoknak, hanem a kisebb cégeknek is lehet versenyelönyük, mivel a kisebb hazai piaci szegmenseket differenciált termékekkel, az új innovációkra épüló, rugalmas termeléssel ki tudják használni.

Az intenziv belföldi versengés az új üzleti formációk megjelenésétől, az új versenytársaktól is függ. Az új belépők általában nagyobb kockázatot vállalnak, rugalmasabbak és az innovációk gyorsabb alkalmazására törekszenek. Két alapmechanizmus során jönnek létre új szervezetek egy iparảgon belül:

- Új, független vállalatot alapítanak (spin-off): valamely létezỏ cégböl kilépö szakértők, a támogató (beszállitó) vállalatok saját termékeik tovább feldolgozására, valamint kutatók saját egyetemi, kutatóintézeti eredményeik hasznosítására létesítenek egy új céget.

- Belsó diverzifikációval egy új cég létrehozása (start-up): a vállalat létrehoz egy új leányvállalatot eszközök, szakemberek, kapcsolatok stb. átadásával, általában egy-egy innováció (alapanyag, félkésztermék fejlesztése stb.) megvalósítására, ekkor nem új versenytárs, hanem a támogató vagy kapcsolódó iparágakban egy kooperáló partner jelenik meg.

Mindegyik globális iparágban eröteljes a verseny, a vállalatok csak akkor tudják versenyelőnyeiket fenntartani, ha készen állnak állandóan arra, hogy versenystratégiájukat, a vállalati szervezetet a văltozó körülményekhez igazítsák. Alkalmazkodókészség nélkül a versenyelönyök nem maradhatnak fenn.

Az elözöekben áttekintettük a rombuszmodell determinánsainak legfontosabb jellemzőit. Az iparágak többségében a véletlennek is szerepe volt a versenyelönyök kialakításában: új tudományos felfedezések (bázisinnovációk), amelyek forradalmasították az iparágat, új alapanyagok kikísérletezése (pl. a szilícium), az árak drasztikus változása (pl. olajsokk), háborúk, természeti katasztrófák stb. A véletlen szerepe aszimmetrikus, pl. a háború a győztesek helyzetét megkönnyíti, a vesztesekét megnehezíti, egy új eljárás a régi módszerek alkalmazóit tönkreteszi (pl. a számítógép a hagyományos írógépek gyártóit). A véletlen elsősorban lehetőséget jelent, melyik ország milyen iparágai, vállalatai képesek gyorsan lépni és kihasználni az alapvetően megváltozott körülményeket.

A versenyelöny az invención, az abból kinövő innováción múlik, az ehhez szükséges vállalkozókészségen. Egy ötlet elvileg bárhol kipattanhat, de az innováció gyors kifejlesztéséhez már döntő az ország által nyújtott üzleti környezet, ezért vagy a feltaláló megy valamelyik fejlett ország centrumába, vagy valamelyik világcég megveszi az ötletet, kifejleszti és piacra dobja a terméket, eljárást, szolgáltatást. Abban a régióban kedvezők a feltételek a kifejlesztéshez, ahol a rombuszmodell versenyelönyöket nyújt az adott iparág számára. 
A rombuszmodellben determinánsonként megadhatjuk hogy milyen üzleti környezeti elemek a lokális versenyelönyök forrásai (4. ábra). Szükséges, de nem elegendő a termelési tényezők mennyisége, fontosabb a minöségük és specializáltságuk, döntö az erőteljes helyi rivalizálás és a befektetéseket ösztönzö környezet, az igényes helyi vásárlók és a versenyképes beszállítók.

A rombuszmodell áttekintéséböl általánosságban megállapitható, hogy ott keletkeznek versenyelönyök, ahol a vállalatok hazai és térségi bázisa egyaránt elösegíti a specializált eszközök és tudás leggyorsabb akkumulációját, ahol a hazai bázis a piaci igényeket előre jelzi, és ahol a tulajdonosok, a menedzserek és az alkalmazottak támogatják az állandó és intenzív megújulást. A nemzetek azokban az iparágakban sikeresek, ahol a hazai környezet a legdinamikusabb és ösztönzi a vállalatokat a versenyelőnyök bővitésére, kiszélesítésére. A nemzetek, régiók sikere nem az elszigetelt iparágakban rejlik, hanem az egymáshoz vertikálisan és horizontálisan kapcsolódó iparágak kooperációjában. A nemzetgazdaság, de a régiók gazdasága is a különböző vállalati kooperációk keveréke, amely forrását nyújtja a versenyelönynek (vagy hátránynak) és visszatükrözi a gazdasági fejlödést is. 


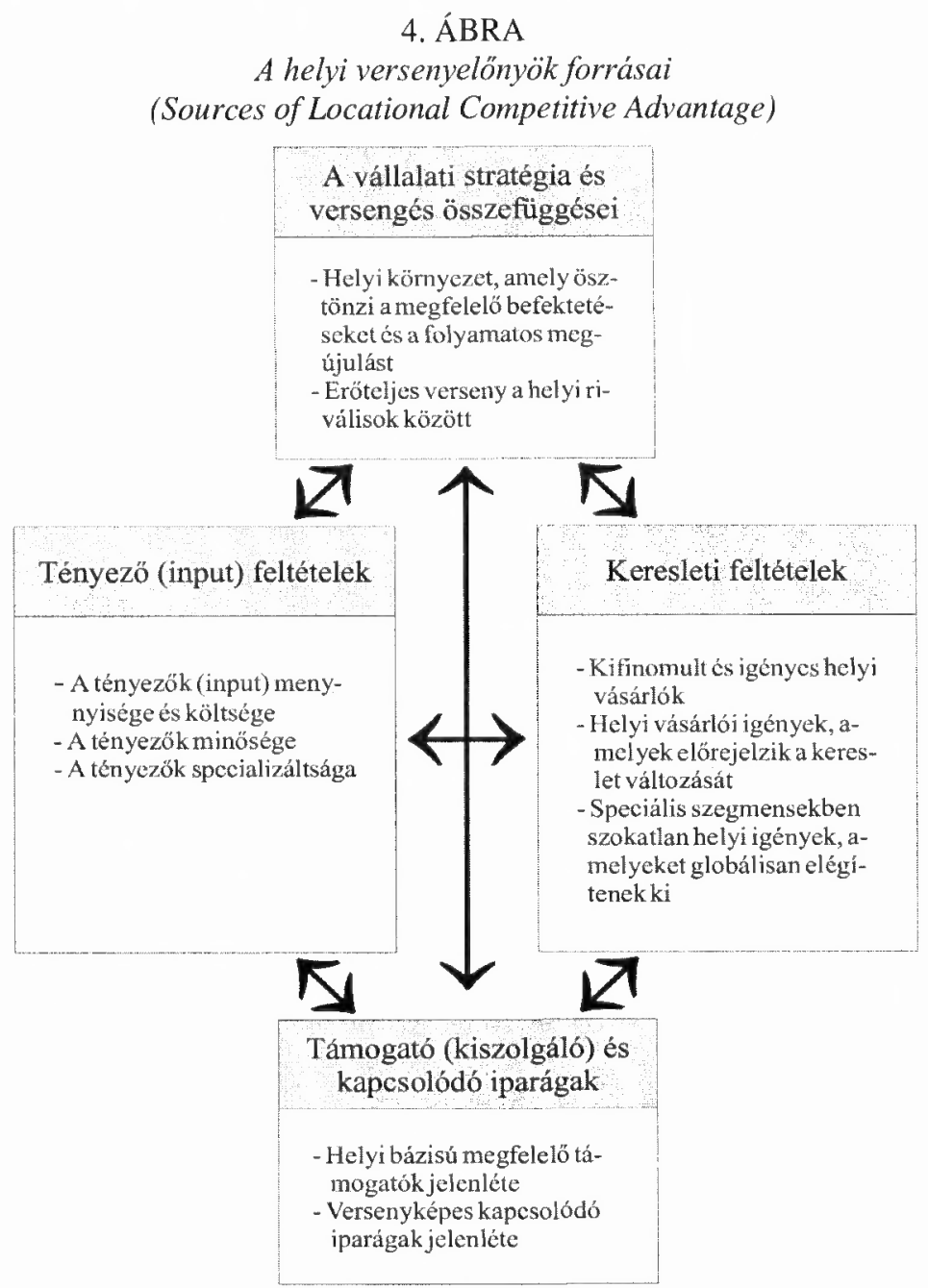

Forrás: Porter $(2000,20)$ alapján saját szerkesztés.

\section{A rombuszmodell mint dinamikus rendszer}

A rombuszmodell elemei kölcsönhatásban állnak egymással, dinamikus rendszerük határozza meg az iparág termelékenységét egy adott régióban. Két elem, a belföldi verseny és az iparág földrajzi koncentrációja bír különösen nagy eróvel a rombuszmodell dinamikus rendszerré transzformálásában: a belfoldi verseny az egész nemzeti rombusz (az országos bázis) fejlődését elömozdítja, míg a földrajzi koncentráció (a térségi bázis) fokozza és felerősíti a rombuszon belüli kölcsönhatásokat.

A rombuszmodell mindegyik determinánsa befolyással bír a modell többi elemére, még ha eltéró módon és eróvel is. A regionális gazdaságfejlesztési stratégiák 
kidolgozásakor alapvetö ezen kapcsolatok kiaknázása, az önerösítö folyamatok elindítása. A fontosabb kölesönhatások:

(a) Az általános termelési tényezőket a központi kormányzatok fejlesztik, általában területileg egyenletesen. De a speciális és fejlett tényezök fejlesztése a regionális és helyi kormányzatok feladata, mivel egyrészt csak a helyiek ismerik a speciális igényeket és feltételeket. Másrészt a régiók vetélkednek egymással, sok esetben ugyanazon iparágat szeretnék fejleszteni több régióban is, ezért egymás ellen is felléphetnek a kormányzatnál, a befektetöknél stb. A régiók vetélkedésében a belföldi iparági rivalizálás miatt a régióban müködö versenyző cégek maguk is részt vesznek. A versenyelönyökhöz szükséges specializált tényezök a régión belüli iparági riválisok összefogásával (pl. szakképzés, informatika, fejlesztó intézetek múködtetése stb.), gazdasági (kereskedelmi) kamarák, iparági szövetségek stb. szervezésében jöhetnek létre (több esetben egyetlen cég önmagában nem tudja létrehozni a versenyelönyt jelentő speciális tényezöt, túl kockázatos és sokba kerül), közösen lehet nyomást gyakorolni a központi és helyi kormányzatra. Továbbá az iparág igényeihez igazodó speciális közjavak fejlesztése akkor hatékony, akkor a legolcsóbb, ha a riválisok egymáshoz közel helyezkednek el, mindannyian ugyanabban a városban vagy régióban müködnek.

(b) A keresleti feltételeket döntöen a hazai rivalizálás befolyásolja (pl. az amerikai üdítöipar: Coca-Cola, Pepsi Cola, Seven Up stb.), az intenzív versengés növeli és igényesebbé teszi a hazai keresletet (reklámok, imázs révén), nö a termékválaszték, megjelennek specializált boltok, kiegészitő szolgáltatások stb. A világszínvonalú támogató és kapesolódó iparágak imázsa is szétterül, túlcsordul (spill over) és növeli az iparág termékei iránti keresletet, a nemzetközileg sikeres iparágak által gyártott kiegészítỏ termékek ráirányítják a figyelmet (és felkeltik az igényeket) a régió többi iparágának termékeire is.

(c) A tâmogató és kapcsolódó iparágakat a specializált tényezőkből eredö „túlcsordulás" segítheti, pl. a szakképzés, az ismeretek, a technológia tapasztalatai, a kapesolatok, egy vállalattól az értéklánc-rendszer többi eleméhez átkerülhetnek. Ez a túlcsordulás föleg akkor hatékony, ha földrajzilag koncentráltan jelenik meg, azaz ugyanazon régión belül fordul elö. Ha az iparág termékei iránt megnő a kereslet, akkor ez kiváltja a támogató iparágak specializációját és egyre több támogató cég jelenik meg. A nemzetközileg sikeres belföldi cégek csoportja a globális igényeket (keresletet) becsatornázza a belföldi támogató iparágakba is, ezáltal egyre több támogató iparág lesz képes kilépni a világpiacra. A rombuszmodell egy olyan környezetet hoz létre, amely támogatja a versenyképes iparágak földrajzi koncentrációját, klaszterek kialakulását. 


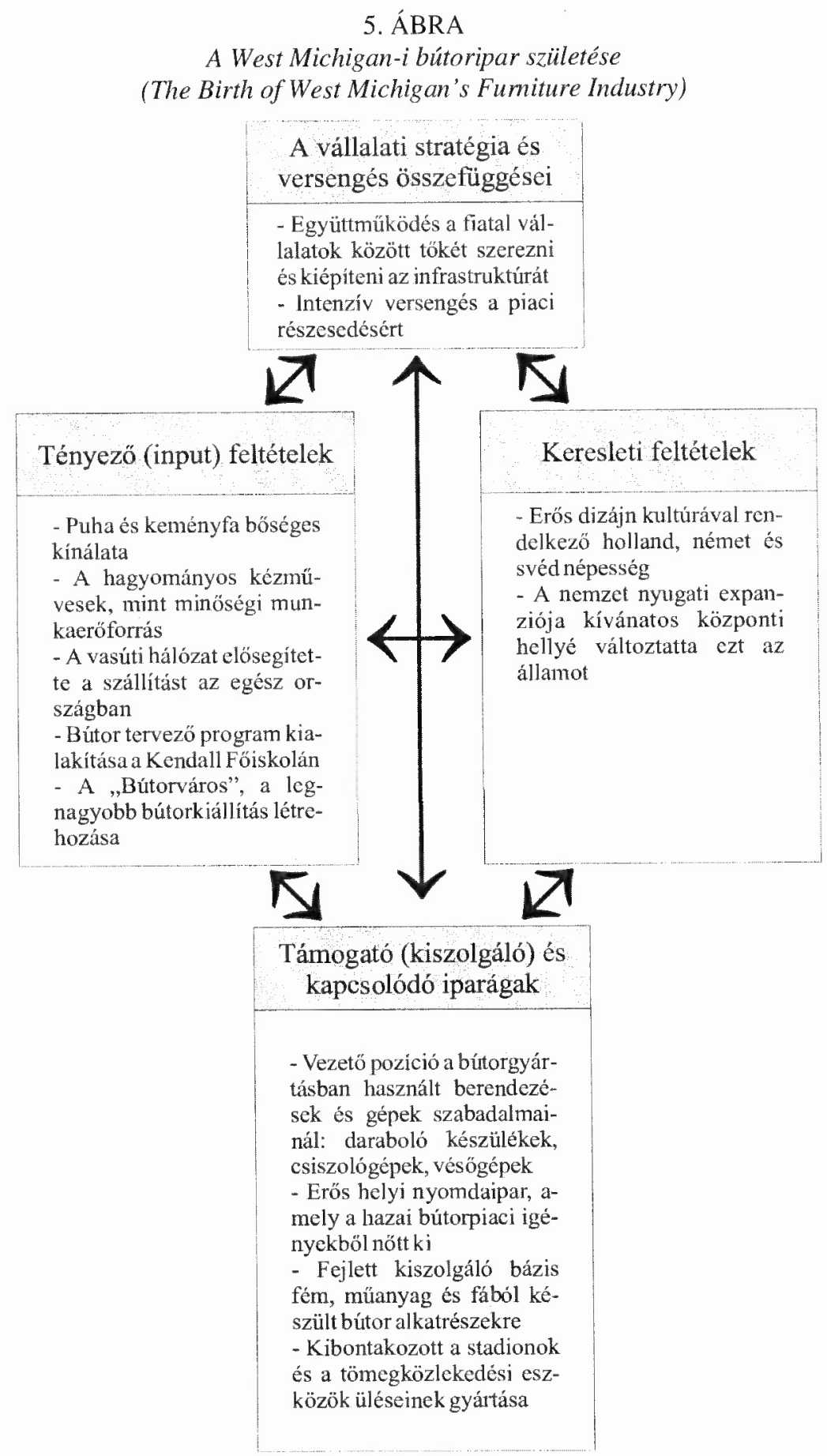

Forrás: Porter $(1997,21)$ alapján saját szerkesztés. 
(d) A vállalati stratégiák újratervezését és a versengés erösödését föleg a keresleti feltételek élénkülése váltja ki, mivel a hazai vásárlók igényessége, vásárlóereje bátorítja ủj cégek piacra lépését is. A piacra újonnan lépö vállalatok egy része a kapcsolódó iparágakból kerül ki, sokszor a versenyelőnnyel rendelkező alkatrészgyártók lépnek elö végtermék előállítóvá. A specializált termelési tényezők bősége is ösztönözheti az új cégek tömeges piacra lépését (pl. világszínvonalú laboratóriumok, kutatóintézetek, szoftverfejlesztö cégek stb.) a régión belül.

A rombuszmodell rendszerként fogható fel determinánsaival és a közöttük levö kapcsolatokkal együtt, amely leírja egy adott iparág versenyelőnyeinek forrásául szolgáló üzleti környezetet. A rombuszmodell, mint rendszer állandó mozgásban van, több esetben nehéz egy iparági versenyelőnyt mint okozatot visszavezetni valamelyik determinánsra. Az iparágak egy részében nem szükséges, hogy a rombuszmodell mindegyik determinánsa fejlett legyen, pl. a természeti eróforrásokra, vagy alacsony technológiára és betanított munkaerőre alapozó költségelönyöknél a belföldi kereslet igényessége nem feltétel. Viszont a magasrendü elönyök mindig több determinánsra támaszkodnak, azaz a determinánsok kombinációjára, de még a legfejlettebb iparágban sem szükséges, hogy minden egyes determináns nemzetközileg fejlett legyen, az esetleges hátrányokat a többi determináns kompenzálhatja. A legtöbb iparágban a nemzeti versenyképesség a széles körben felhasználható általános termelési tényezők és az egyes iparágakra jellemző speciális tényezők kombinációjából állnak. A tényezőellátottság jelenlegi összetétele kevésbé fontos, mint a tényezőket generálni, létrehozni képes speciális intézmények és intézményi mechanizmusok jelenléte. A dinamikus elönyöket nyújtó feltételek (gyorsabb innováció, korán elért előnyök, késztetés a bővítésre) fontosabbak, mint az örökölt statikus elönyök (pl. a természeti erőforrások vagy a nagy hazai piac).

A régióban egy iparág létrejöttének feltételei, versenyelönyének kialakulása leírható a rombuszmodellel (5. ábra). Pl. West Michigan-ben a bútoripar (bútoripari klaszter) termékei iránt igényes helyi kereslet jelentkezett, amely a kedvezö tényezőkkel (helyi alapanyag, minöségi munkaerö, szállítási lehetőségek) és az intenziv helyi versengéssel párosulva lehetővé tette az iparág megerösödését, amit tudatosan is támogattak (főiskolai képzés, országos kiállítás). A bútoripar keresletet támasztott a támogató iparágak, gépek és eszközök, nyomdai termékek iránt, amely iparágak szintén megerősödtek, valamint egyes kapcsolódó iparágak (pl. stadionok székeinek gyártása) is kifejlödtek ugyanezen koncentrált tudásbázisra támaszkodva.

\section{Regionális klaszterek}

Az ország, régió versenyképességénél nem az egyes determinánsok fontosak, hanem a rombuszmodell mint rendszer egésze, amely lehetővé teszi, hogy a régióban mint térségi bázisban nemzetközileg sikeres iparágak múködjenek és versenyelönyeiket tartósan fenn tudják tartani. Azaz a régió versenyképessége azt jelenti, hogy a régióban sikeres értéklánc-rendszerek múködnek, a piaci kereslet változásakor, új 
versenytársak fellépésekor pedig az értéklánc-rendszer fennmaradását vagy megújulását előidéző mechanizmusok lépnek életbe.

Egy-egy vállalat, iparág versenyelőnyei a székhelyének, illetve lényegi tevékenységeinek helyet adó országtól, mint hazai bázistól és az országon belüli térségtől (térségi bázistól) függnek. Porter az értéklánc-rendszert (ellátási láncot) meghaladva, továbbfejlesztve a regionális klaszterek jelentőségét emeli ki, amelyek az adott térségben müködö versenyzö és kooperáló vállalatok, a kapcsolódó és támogató iparágak, a pénzügyi intézmények, a szolgáltató és együttmüködö infrastrukturális intézmények (oktatás, szakképzés, kutatás) és vállalkozói szövetségek (kamarák, klubok) szervezeteinek innovatív kapcsolatrendszerén alapuló földrajzi koncentrációi (Lengyel 2000b; Porter 2000, 16). A klaszter lényegében ugyanazon iparágba tartozó vállalatok és a velük szorosan együttmüködö más iparágbeli vállalatok együttese, olyan egymáshoz kapcsolódó értéklánc-rendszerek összessége, amely földrajzilag koncentrálódik, és amelyhez nemcsak vállalatok, hanem intézmények is tartoznak (lásd 5. ábra, amely lényegében bútoripari klaszter).

Egy klaszter vállalatai és intézményei ugyanazon lokalizált tudásbázisra, munkaerőbázisra és infrastruktúrára támaszkodnak, valamint hasonló innovációkat hasznositanak, azaz együtt tudnak múködni a kutatás-fejlesztés több területén is. Amíg az értéklánc-rendszerben mint vállalati hálózatokban a vállalatok ủzleti kapcsolatban állnak egymással, addig a klaszter jóval nyitottabb, mivel informális kapcsolatokon, vállalkozói összejöveteleken, klubokon stb. keresztül is „face-to-face” módon áramlanak az információk. A termékdifferenciálás miatt a klaszter szintjén jelentkező pozitív externáliák általában fontosabbak, mint a költségekben mérhető urbanizációs előnyök. Porter az agglomerációs elönyöket fejlesztette tovább a globális feltételekből kiindulva, véleménye szerint manapság nem az elkülönült vállalatok versenyeznek, hanem a regionális klaszterek, ezért egy új mikroökonómiát kellene kidolgozni, amelynek alapegységei a klaszterek lehetnének (Porter 1998b).

A klaszterekre nagyon sok példa hozható fel (Porter 1990; 1998a; Döry 1998; OECD 1999; Grosz 2000) pl. Emilia-Romagna tartományban ruházati, kerámiai, bútoripari, cipöipari klaszterek, Baden-Württembergben textil-, szerszámgép-, autóalkatrészgyártás, a Szilícium-völgyben mikroelektronikai és biotechnológiai, Los Angeles-ben szórakoztatóipari, Dél-Floridában egészségügyi technológiai, Finnországban telekommunikációs, Dániában enzim-klaszter, Wales-ben elektronikai és gépjármüipari klaszter stb. Porter az 1990-es évek közepén az Egyesült Ảllamokban végzett felmérés alapján közel 60 regionális klasztert mutat be, amelyek között ingatlanfejlesztési (Dallas), kockázati tőke (Szilícium-völgy és Boston), szórakoztatóipari (Las Vegas), kórházi menedzsment (Nashville) klaszter stb. is elöfordul (Porter 1998c). A sikeres klaszterek nagyon sokféle módon jöttek létre, meghatározók a tradíciók, a kulturális adottságok, az együttmúködési készség, a bizalom, a kreatitivás stb. (Buzás 2000; Gordon-McCann 2000).

A regionális klaszter lényege a rombuszmodellböl ered, hogyan cserélödik és áramlik az információ a piaci szükségletekröl (a jövöbeli igényekröl, a várható kereslet változásairól), a technikai eszközökröl (a tapasztalatokról) és a technológiá- 
ról az iparág vállalatai, valamint a vásárló (a termék használója), a támogató és a kapcsolódó iparágak, az innovációs kapacitás és munkaeröképzés helyi intézményei között (Deák 2000). A klaszterek alapvetö sajátossága a kommunikáció, amelynek egy része nem kötött a helyhez (telefon, internet stb.), viszont a bizalmon, személyes ismeretségen, tartós kapcsolatokon, a „,zomszédságon” alapuló kommunikáció elönyöket hordozhat. Ez az információ-csere azt jelenti, hogy szinte tökéletesen informált mindegyik résztvevő, ezért hatékony döntést tudnak hozni, így a régió erőforrásainak felhasználása is jelentösen javul. Lényegében a régióban levő ,,kollektív tudást" tudják hasznosítani a klaszterek szereplöi, egyúttal minimalizálva információszerzési és egyéb tranzakciós költségeiket.

Egy klaszter jóval több, mint vállalatok összessége, mivel olyan közös fejlesztéseket is létrehozhatnak, amelyek minden egyes cég gazdasági helyzetét javithatja, de külön-külön nem lennének képesek megvalósítani forrásaik szükössége miatt. Az egész régióban, kistérségben olyan fejlesztések, közszolgáltatások jöhetnek létre, amelyek pozitív externhatást fejtenek ki mindegyik ott müködő vállalkozás számára (Hill-Brennan 2000). Továbbá egy klaszter az iparág/üzletág fogalmánál szélesebb értelmü, ugyanis nemcsak vállalatok, hanem intézmények is beletartoznak, és a speciális kutató, fejlesztö, oktatási, tanácsadó, jogi stb. intézményeken kívül, a lokális kulturális és vállalkozói attitüdöt, az innovációs miliőt (együttmúködési készség, kreativitás stb.) is beleértjük. A klaszterek kialakulása, az együttmúködést alakító mechanizmus országonként eltérö, föleg a nemzeti sajátosságoktól függ.

Egy regionális klaszterben nemcsak az elönyök elérése a cél, hanem ezzel összefüggésben a hátrányok mérséklése is, a kockázat, a bizonytalanság (pl, technológiai fejlesztésnél) csökkentése. A klaszterben levö vállalkozások a helyi munkaeröpiacon nagyjából egységesen tudnak fellépni, nem indítanak árversenyt, hanem inkább a termékdifferenciálást helyezik elötérbe, az inputhelyettesítés során pedig arra törekszenek, hogy ne rontsák egymás pozícióit, azaz nem indítanak bérversenyt sem (nem csábítják át mástól a legjobb szakembereket, nem vásárolják fel spekulációs célból az alapanyagokat stb.).

$\mathrm{Az}$ általános termelési tényezök egyre több helyen hozzáférhetök, ezért a globalizáció korában a fejlett országokban a versenyelőnyt a szűkösen rendelkezésre álló, specializált tényezök határozzák meg. Ezek az iparáganként eltérő specializált tényezök térben is szükösek, lokalizáltak, csak néhány városban, régióban találhatók meg (pl. magas szintü alkalmazott kutatások), ebből adódik, hogy egy iparág nemzetközileg sikeres versenyzöi, a hozzájuk kötödő klaszterek gyakran egy régióban helyezkednek el. Nemcsak az iparágak, hanem a támogató iparágak nagy része is ugyanabban a régióban található és több esetben a legnagyobb vásárlók is (a termék továbbfelhasználói), avagy a kifinomult ízlésủ és igényes vásárlók (amelyek gyakran csúcstechnológiai vállalkozások). Az értéklánc-rendszer lényeges elemeinek, a támogatók és vásárlók, valamint a riválisok földrajzi koncentrációjának hatására csökkennek a kommunikációs és szállítási költségek, javul a hatékonyság és erősödik a specializáció (ami a termékdifferenciálás kiindulópontja). 
Az innovációk térségi bázison belüli diffúziója a szomszédsági hatáson alapul, ekkor a leggyorsabb a terjedés és a legkisebb az információveszteség.

\section{A kompetitiv fejlödés szakaszai}

A rombuszmodell mindegyik determinánsából adódhatnak versenyelőnyök, ha nincs kiaknázatlan általános tényezö (pl. szakképzett munkaerö, olcsó természeti erőforrás stb.), akkor a rombuszon belül kell öngerjesztő folyamatot elindítani, a területfejlesztés során tudatosan létrehozni a régió, térség perspektivikus iparágainak háttérfeltételeit. A folyamatok általános szempontjai:

- a nemzetközi versenyelönyök kezdetben általában valamilyen örökölt termelési tényezőn alapulnak,

- a fejlett gazdaságokban előtérben állnak a specializált termelési tényezőket elöállító mechanizmusok (pl. szakképzés, kutatás stb.),

- a keresleti feltételek élénkülése is ösztönözheti versenyző cégek alapítását,

- a fejlődő országokban vagy az alapvető tényezők, vagy a növekvő helyi kereslet miatt alakulhatnak ki versenyágazatok,

- egyes versenypozíciók elvesztése gyakran a gazdaság egészségének jele, ugyanis a vállalatok a standardizált, alacsony technológiai igényủ, árérzékeny (költségelőnyökön alapuló) szegmensböl mennek át az előnyösebb iparágakba, amelyek innovációigényes és differenciált termékeket állitanak elö.

\section{6. ÁBRA}

A kompetitiv fejlödés folyamata

(Processes of National Competitive Development)

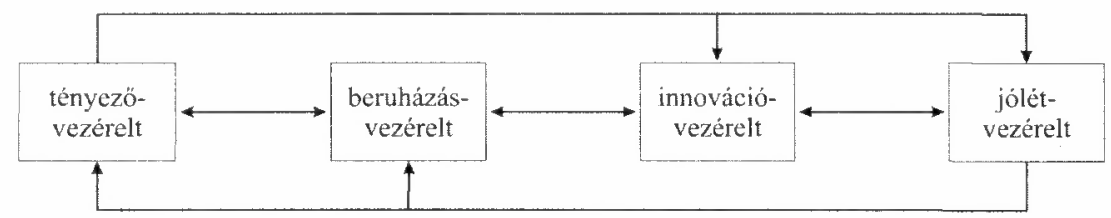

Forrás: Porter (1990, 563) alapján saját szerkesztés.

Porter a nemzetgazdaságok fejlődését a nemzetközi versenyre vezette vissza, az országok domináns iparágai hogyan tudtak megfelelni a globális verseny feltételeinek. A gazdasági fejlödés helyett a kompetitiv fejlödés kifejezést használva négy egymást követö, illetve egymással kapcsolatban levő szakaszt különböztet meg (6. ábra).

Mindegyik szakaszban az a lényeg, hogy miböl ered, mire vezethetö vissza a nemzet versenyelönye (Porter 1990, 543-573):

- Tényezö-vezérelt egy nemzetgazdaság fejlődése, amikor az általános termelési tényezőkböl származik a versenyelőny (természeti erőforrások, alacsony képzettségủ és olcsó munkaerő stb.), azaz a rombusznak csak egy determinánsa jelent versenyelőnyöket. Ekkor az iparágak vállalatai az árverseny kihasználását, a költségelőnyt helyezik előtérbe, a technológia alacsony szintủ és más országból vásárolták, nem saját fejlesztésủ. A vállalatoknak ritkán van kapcsolatuk a termékek végső felhasználóival, emiatt lassan érzékelik a kereslet vál- 
tozását, az ilyen gazdaság érzékeny a világpiac ciklusaira, az árfolyamváltozásokra. A fejlődő országok szinte kivétel nélkül ebbe a csoportba tartoznak.

- Beruházás-vezérelt gazdaságban az általános termelési tényezők mellett a fejlett tényezőkbe történnek eröteljes és agresszív beruházások, a belföldi verseny egyre intenzívebb, mind az egyének, mind a vállalatok motiváltsága erösödik, a belföldi kereslet mérete és növekedése versenyelőnyöket hordoz magával, azaz a rombusznak két-három determinánsán alapulnak a versenyelönyök. A vállalatok a világpiacon elérhető legjobb technológiákat külföldröl vásárolják meg és alkalmazzák, amelyek méretgazdaságosságból eredỏ elönyöket jelentenek és a termelékenység ugrásszerüen javul, de ezek a technológiák általában nem a legújabbak (azokat a vezető cégek nem adják tovább), ezért javitásukra és fejlesztésükre is eröfeszitések történnek. A kormányok a modern műszaki (autópályák, repülőterek, energetikai hálózatok stb.) infrastruktúra mellett a szakképzésre, a müszaki és üzleti ismeretek szétterjesztésére is törekszenek. A képzettebb munkaerö és a növekvő technikai ismeretek alacsony bérekkel társulnak, ami forrását jelenti a további beruházásoknak. A vállalatok kiépítik nemzetközi kapcsolataikat, az iparágak egy szük körében megteszik az első lépéseket nemzetközi versenyelönyök szerzésére, amelyek föleg alacsony bérköltségeken és tömegtermékeken alapszanak. A kormányzati politika arra irányul, hogy néhány kiválasztott iparág versenyelönyökre tegyen szert, ennek érdekében exporttámogatást nyújt, protekcionista politikát folytat, az infrastruktúrát a kedvezményezett iparágak igénye szerint fejleszti (képzést, közlekedési rendszert stb.).

- Innováció-vezérelt gazdaságban a rombusz mindegyik determinánsa és a közöttük levö kapcsolatok egyaránt versenyelőnyöket jelentenek. A belföldi keresletnek van igényes szegmense, a vállalatok globális versenystratégiákat dolgoznak ki, a kapcsolódó és támogató iparágak kiépülnek, a fejlett és specializált termelési tényezők létrehozásán van a hangsúly. Nemcsak vásárolnak technológiákat, hanem fejlesztenek is új innovációkat, amelyek föleg az új fogyasztói igényeket kielégíteni képes termékek előállításához kötődnek. Elöször vertikális klaszterek jönnek létre, majd a dinamikus gazdaságokban horizontális klaszterek is a sikeres iparágak együttmüködéséböl, amelyek a specializáció folytán lokálisan is koncentrálódnak. Jellemzö, hogy megjelennek az igényes szolgáltatásokra épülő olyan új iparágak, amelyek nemzetközi versenyelönyökkel bírnak. A kormányzati politika elveszti korábbi kiemelkedő szerepét, a magánszektor válik a termelési tényezök fejlesztésének föszereplőjévé. A kormányzat indirekt módon ösztönzi fejlett tényezök létesítését, a belföldi versengés erösödését, új üzleti vállalkozások létrejöttét, klaszterek kialakulását stb., azaz a versenyképességet próbálja javítani.

- Jólét-vezérelt gazdaság esetében mind a befektetők, mind a menedzserek elvesztik az innovációk és a fejlesztés iránti késztetésüket, nem vállalják a kockázatot, a gazdasági versenyelönyök fenntartása helyett társadalmi célok kerülnek előtérbe. A gyengülő hazai verseny, a belföldi kereslet stagnálása, a klaszterek gyengülése, az ösztönzés háttérbe szorulása a vállalati versenyelönyök elveszté- 
séhez vezet, azaz a gazdaság stagnál vagy visszahanyatlik. Fennmaradhat néhány iparágban a versenyelöny, pl. a kifinomult igényeket kielégítő termékek, a magas presztízsü termékeket elöállitó történelmi gyökerü iparágak, a hosszú időn keresztül akkumulálódó tudású iparágak (pl. alapkutatások) stb.

A fenti szakaszos fejlödési modell a versenyelönyök szempontjából értékeli a vizsgált tiz országot a második világháború végétöl a nyolcvanas évekig terjedő időszakban. Szingapúr és Korea a tényezö-vezérelt szakaszból eljutott a beruházásvezérelt szakaszba, Olaszország és Japán pedig a tényezö-vezérelt szakaszból az innováció-vezéreltbe (Japán a kilencvenes években továbblépett a jólét-vezéreltbe). Dánia és Svédország az innováció-vezérelt szakaszban maradt, illetve részben visszacsúszott a beruházás-vezéreltbe. Svájc, Németország és az USA az innovációvezérelt szakaszból nagyjából a jólét-vezéreltbe lépett át, míg az Egyesült Királyság a jólét-vezéreltből visszacsúszott, de a nyolcvanas évek közepén még nem volt felbecsülhetö, hogy melyik szakaszba (azóta az Egyesült Királyság átkerült az innováció-vezéreltbe).

A kompetitív fejlödés szakaszai logikusan következnek a versenyelönyök forrásait tekintve, de nehéz az egyes iparágak versenyelönyei alapján következtetéseket levonni az aggregált versenyelőnyre, emiatt bírálták is Portert, ugyanis szinte mindegyik országban megadhatók olyan iparágak, amelyek különbözö szakaszban vannak. Érdekessége a kompetitív fejlödésnek, hogy nem épülnek mereven egymásra a szakaszok, hanem visszafejlödés is lehetséges, azaz a különböző fejlödési szakaszok váltogathatják egymást. Magyarországot a tényezö-vezérelt szakaszba sorolhatjuk (olcsó és szakképzett munkaerö mint versenyelöny), amely megkezdte az átmenetet a beruházás-vezérelt szakaszba.

\section{Alulról szervezödő regionális gazdaságfejlesztési stratégia}

Porter egész gondolatmenete, kiinduló állitásai és rombuszmodellje lényegében egy alulról szerveződő regionális gazdaságfejlesztési stratégiát (továbbiakban: ARGS) vázol. Alulról szerveződő, mivel néhány kulcsiparág/klaszter versenyelönyének javításaként fogalmazza meg a régió gazdaságfejlesztésnek célját, a többi iparág és a helyi gazdaság fejlödése pedig a regionális multiplikátorhatásoktól várható el.

Egy adott iparágat tekintve a tartós versenyelönyök fö forrása a tevékenységek specializációja és az innovációs készség, amely elsősorban lokális tudásbázisra támaszkodik. A szükös iparági tudásbázis szükségszerủen földrajzilag is koncentrálódik a hazai bázison belül néhány régióra és városra, ahol öngerjesztö folyamatok indukálódnak és ezáltal a versenyelőnyök fennmaradhatnak. Az iparági tartós versenyelönyöket Porter négy determinánsra és dinamikus rendszerükre, a rombuszmodellre vezette vissza, az így rendszerezett mikroökonómiai üzleti környezetből adódó versenyelőnyöket legjobban a regionális klaszterek képesek kihasználni. $\mathrm{Az}$ erös globális verseny következtében a fejlett országokban szükségszerüen létrejönnek a regionális klaszterek mint a termelékenység javításának legelőnyösebb háttérfeltételeit nyújtó szerveződések, így a globális verseny lényegében régiók 
versenye, amelyek csak akkor lehetnek sikeresek, ha (verseny)stratégiát dolgoznak ki fejlesztési koncepciójuk megvalósítására.

Amíg a területi stratégiák, pl. a kereslet-orientált és a kínálat-orientált stratégia is a régió gazdaságába „kívülröl avatkozik be”: területfejlesztési (gazdaságon kívüli) célokat fogalmaz meg, helyi politikai szempontokat és szereplöket helyez elötérbe, a fejlesztések nagyobb részét is külső, régión kívüli forrásokból finanszírozza, addig az ARGS döntően helyi vállalatok fejlesztési céljait hozza összhangba, és föleg a helyi magánszektor forrásaira támaszkodik (Korompai 1995; Rechnitzer 1998). Az ARGS esetén a helyi kormányzat nem irányítja a gazdaságfejlesztést, hanem kiszolgálja a gazdasági szereplöket és teljesíti a klaszterek elvárásait az általános tényezök fejlesztésével kapcsolatban. Az ARGS fő koordinálói az önszerveződés során létrejött iparági szövetségek, szakmai szervezetek, fejlesztö ügynökségek, illetve a forrásokat nyújtó és a fejlesztéseket végrehajtó gazdasági szervezetek.

A kilencvenes években széles körben elterjedt Porter felfogása, egyre-másra születtek empirikus vizsgálatok az iparágak rombuszmodelljének tesztelésére, sőt az Egyesült Államok tagállamainak és régióinak nagy részében a klaszter-alapú gazdaságfejlesztést helyezték előtérbe (Healy-Dunham 1994; Kaufman et al 1994; O'Shaughnessy 1996; Maskell et al 1998; Waits 1998; 2000; Drejer et al 1999; Rouvinen-Yla-Anttila 1999). Megjegyezzük, hogy Porter nem foglalkozott közigazgatási régiók fejlesztésével, az ő szemléletében a klaszter térbeli kiterjedése, a gazdaság térkapcsolatai a lényegesek, azaz a csomóponti régiók, amelyek átléphetik a közigazgatási határokat, illetve akár egy városrészre is koncentrálódhatnak (Lengyel 2000b). A következőkben röviden felvázoljuk az ARGS hazai adaptációja föbb lépéseinek tartalmi kérdéseit Porter klaszter-alapú gazdaságfejlesztési gondolatai, valamint az OECD egyik munkabizottsága (Cluster Focus Group) javaslatai alapján (Porter 1998a; OECD 1999).

Az ARGS célja egyértelmü: a régió versenyképességének erősítése, amely Porter szerint egyet jelent a régióban folyó gazdasági tevékenységek termelékenységének javításával. A termelékenység javítását három fö tényezöcsoportra vezetjük vissza (1. ábra):

- a regionális környezetre, továbbá a mikroökonómiai alapok két összetevöjére,

- a vállalati müködés és stratégia kifinomultságára, valamint

- a mikroökonómiai üzleti környezetre (a rombuszmodellre).

A makroökonómiai háttérfeltételek a régió fejlesztése sorản adottnak tekinthetök, nem változtathatók. Közülük négy olyan feltételt emelünk ki, amelyek nélkül a helyi kezdeményezésen és összefogáson alapuló ARGS-k kidolgozása lehetséges ugyan, de végrehajtásuknak alig van esélye:

- a klaszter-alapú gazdaságpolitika megerősödése az ágazati gazdaságpolitikák rovására,

- decentralizált területfejlesztési politika, illetve ebből adódóan

- decentralizált regionális intézményrendszer, amely a helyiek által választott képviselőtestületböl és az általa felügyelt végrehajtó szervezetből áll, és

- a GDP jelentős része helyben marad (a vállalatoknál, a tőke- és munkatulajdonosoknál, illetve helyi adók formájában), és nem kerül újraelosztásra. 
Az ARGS fö részei, a felsorolásokban jelezve azokat a programokat, amelyek a legtöbb országban megjelennek a régiók stratégiáiban:

1) A regionális környezet (makroökonómiai) részeként:

- az iparági/klaszter-szemlélet elfogadtatása a helyi szereplökkel,

- vállalati szövetségek, kamarák létrejöttének és müködésének ösztönzése,

- innovációs fejlesztő ügynökségek, tanácsadók létrehozása.

2) Helyzetfeltárás:

- a régió gazdasági szerkezetének feltérképezése,

- a domináns iparágak/klaszterek meghatározása,

- egyenként a kijelölt iparágak versenyelỏnyeinek és -hátrányainak felmérése,

- a rombuszmodell mindegyik determinánsára SWOT-analízis elvégzése (7. ábra).

3) Iparáganként/klaszterenként a vállalati müködés és stratégia kifinomultságának erösitése:

- iparági szövetségek, klubok, rendezvények szervezése,

- kereskedelmi társaságok (kamarák) alapítása a klaszter tagjaiból,

- iparági „benchmarking” végzése (külföldön és itthon) és információk gyüjtése,

- speciális iparági tréningek és továbbképzések szervezése,

- egyetemi szakok indítása az iparág szakember utánpótlásának biztosítására.

4) Iparáganként/klaszterenként a rombuszmodell determinánsainak javítása:

- tényezőfeltételek: a magasrendủ előnyök javítása (innovációs centrumok, adatbázisok kialakítása, kommunikációs infrastruktúra kiépítése),

- támogató és kapcsolódó iparágak: klaszter-orientált szabad kereskedelmi zónák, logisztikai központok, ipari parkok kialakítása,

- keresleti feltételek: független termékminösítö szolgáltatások, vizsgálati laboratóriumok, helyi fogyasztóvédelmi elöírások, környezeti szabványok,

- vállalati stratégia és rivalizálás: közös külföldi rendezvények, közös fellépés különböző piacokon. 


\section{7. ÁBRA}

A finn telekommunikációs klaszter rombuszmodellje (The Diamond of the Finnish Telecommunications Cluster)

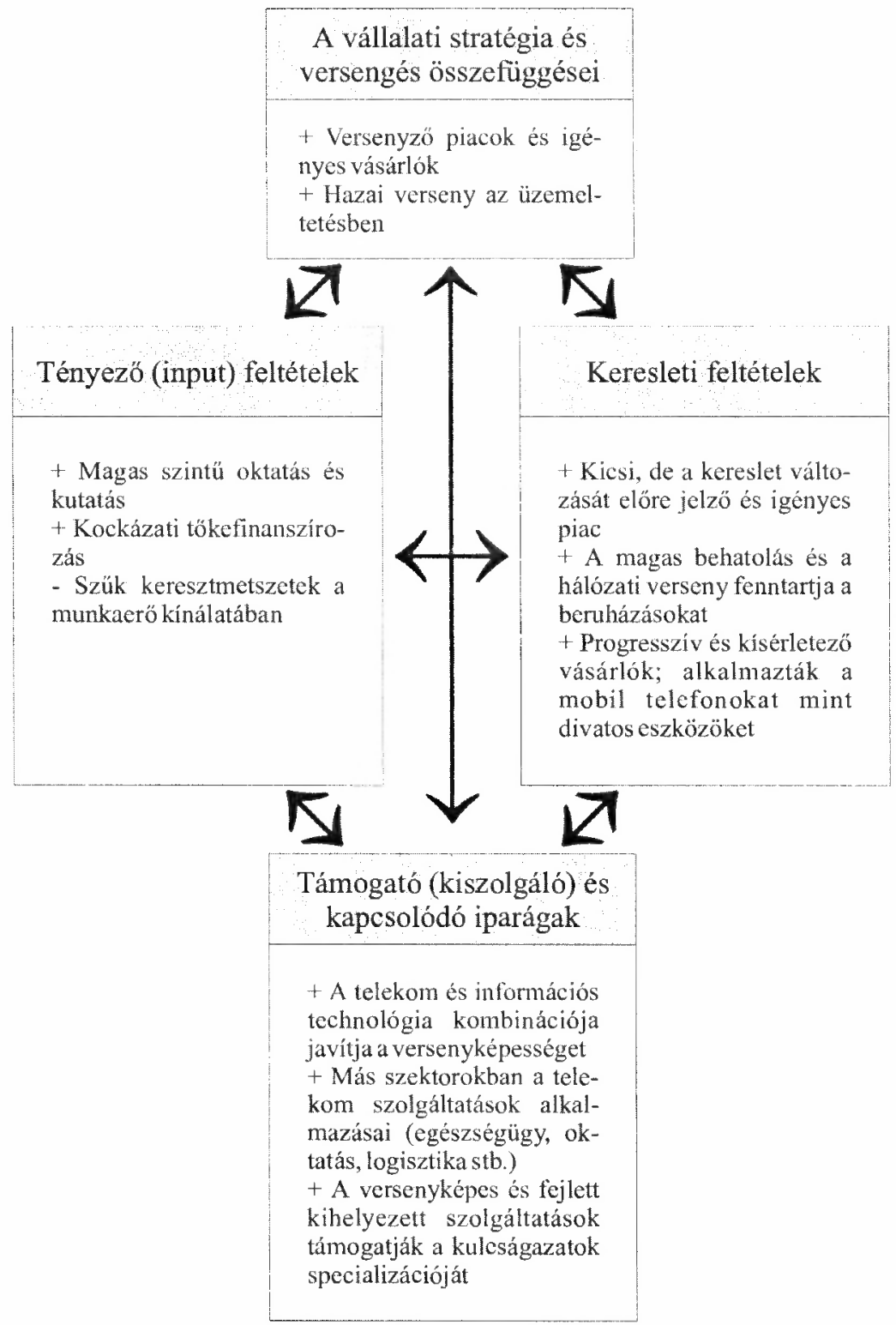

Megjegyzés: a SWOT-analízisnél t az erösség, - a gyengeség jele.

Forrás: Rouvinen-Yla-Anttila $(1999,371)$ alapján saját szerkesztés. 
A helyzetfeltárás során mindegyik iparág rombuszmodelljét, azaz a determinánsok versenyelőnyeit célszerú elemezni, amire a finn telekommunikációs klaszter kiváló példa (7. ábra). Determinánsonként SWOT-analízist végezve meghatározhatók azok a tényezök és jellemzők, amelyek mint erösségek a versenyelönyökhöz hozzájárulnak, illetve a gyengeségeket, amelyek versenyhátrányokat okoznak. A finn telekommunikációs klaszternél még három jellemzőt figyelembe vettek: a kormányzat szerepét, a véletlen hatásait és a külföldi befektetéseket (RouvinenYla-Anttila 1999).

$\mathrm{Az}$ előzőekben vázolt lépések és fejlesztési javaslatok logikusan következnek Porter ismertetett gondolataiból: olyan gazdaságfejlesztést kell megvalósítani, amelynek fő célja a régió globális iparágai termelékenységének javítása négy fö szempontot, a rombuszmodell determinánsait kiemelve. Azaz egy régió gazdaságfejlesztésében iparági prioritások megadását javasolja, amelyekre a régió szűkös forrásait (szakképzett munkaerö, $\mathrm{K}+\mathrm{F}$, infrastruktúra, pénzügyi eszközök) koncentrálni szükséges; pl. az EU-ban a regionális innovációs rendszerek esetében 6-8 stratégiai iparágat szokás kijelölni (Döry-Rechnitzer 2000). Ez a gondolatmenet hasonlít az exportbázis elméletre, így a régió többi iparága (a helyi gazdaság) a multiplikátorhatásokra támaszkodhat.

Magyarországon az elmaradott régiókban általában nincsenek globális iparágak, avagy csak külföldi érdekeltségủ vállalatok telephelyei mủködnek, így az iparágnak máshol van a térségi bázisa, azaz föleg a tényezö-, vagy beruházás-orientált fázis jegyei figyelhetők meg. Ekkor pedig a rombuszmodellnek csak egy-két determinánsából (általában tényezőfeltételek, támogató és kapcsolódó iparágak) származhatnak versenyelőnyei, míg a kereslet, vagy a vállalati stratégia kérdései a régión kívül dőlnek el (Czakó 1997). Egy régió versenyképes gazdasági szerkezetének kialakítására, a globális iparágak térségi bázisának létrehozására az Egyesült Államokban négy fázist javasolnak (szerkezetváltás, helyi gazdasági bázis, újraszervezés, új helyi iparágak), amely lépések itthon is hasznosíthatónak tủnnek (Waits 1998).

\section{Összegzés}

A tanulmányban áttekintettuik Porter munkái alapján a rombuszmodellt, amely a régiók gazdaságfejlesztési stratégiai programozásához kiváló alapokat nyújt. Porter a globális iparágak versenystratégiáit elemezve ismerte fel, hogy az iparágak többségének versenyelőnyei egy földrajzilag koncentrált üzleti környezetben gyökereznek. A lokális versenyelőnyök forrásait rendszerezte rombuszmodelljében, amely rendszerezés elvi alapjait nyújtja egy-egy iparág versenystratégiája kidolgozásának. Egy régió gazdaságfejlesztésének fó célja pedig a régióban térségi bázissal rendelkező versenyképes globális iparágak versenyelönyeinek kialakítása és fenntartása. Porter szemlélete és gondolatai széles körben elterjedtek, munkásságát a vállalatgazdaságtanban nagyra értékelik. Viszont a regionális tudományban kevésbé alkalmazzák javaslatait, ami föleg arra vezethető vissza, hogy a felhasznált ismeretanyag (fogalmak, állítások, hivatkozások stb.) nem közismert a regionalisták köré- 
ben. Jelen tanulmányban ezen probléma feloldására tettünk kísérletet. Megjegyezzük, hogy megállapításai a fejlett országok globálisan versenyző iparágaira érvényesek, a sikeres régiókat modellezi, egyúttal a kevésbé fejlett régiók számára kiváló bottom-up gazdaságfejlesztési stratégiát vázol fel.

Porter a nyolcvanas évek végén eredetinek tủnő fogalmakon alapuló gondolatkörrel állt elő, amelyet a közgazdaságtudomány új paradigmájának igényével fogalmazott meg, szándékai szerint választ adva a globalizáció kihívásaira. Gondolatai a globális iparágakban megfigyelhető verseny általánositásából adódnak, azaz mikroökonómiai felfogásból indul ki. Az általánosan elfogadottnak tủnik, hogy elmélete nem felel meg teljes mértékben a közgazdaságtudományi elméletekkel szemben támasztott követelményeknek, viszont egyes részeredményei széles körben elterjedtek és beépültek a különböző részdiszciplínákba, föleg az alkalmazott gazdaságtanokba és a regionális gazdaságfejlesztésbe. A teljesség és az értékelés igénye nélkül felsorolásszerủen néhány megjegyzést füzünk elméleti jellegü gondolataihoz:

- A Marshall-féle agglomerációs gazdaságok előnyeire vezeti vissza az iparágak földrajzi tömörüléseit, továbbá a növekedési pólus és a gazdasági báziselmélet bizonyos eredményeire.

- Az intézményi közgazdaságtan alapgondolataira is épít, a térségi klaszterek versenyelönyeinek elemzésekor a tranzakciós költségekre támaszkodik, továbbá kiemeli a szinergiai jelentőségét.

- Elméletében marketing elemek is megjelennek, a keresleti feltételek jellemzöinek kihangsúlyozása, ami a közgazdaságtudomány elfogadott paradigmáitól általában idegen.

- Szemlélete és fogalomrendszere a stratégiai menedzsmentböl ered, melynek egyik vezető egyénisége, az iparági versenystratégiák, versenyelönyök kérdéseiben széles körben elismert eredményeket ért el.

- Részben Rostow szakaszos fejlödési elméletére támaszkodva felvázolja a kompetitív fejlödés elméletét, amely elmélet Schumpeter gondolataihoz és a Kondratyev-ciklusokhoz áll közel.

- A termelési tényezők új csoportosítására támaszkodik, a vállalkozói készséget két részre bontja, vállalati stratégiákra és kapcsolódó, támogató iparágakra.

- A széles körben használt termelési függvények helyett négy determinánsból álló modellre vezette vissza a termelékenység növekedését, viszont a determinánsok között mérhető, azaz függvényszerủ összefüggéseket nem állított fel.

Porter empirikus vizsgálatok alapján, támaszkodva a globális iparágakban végzett korábbi versenystratégiai munkáira, az országok, régiók versenyképességének javítását az iparági rombuszmodellekre vezeti vissza. A modell determinánsainak leírásakor az iparági stratégiáknál alkalmazott szempontokra épít, azaz a vállalati versenyelönyök szerint értékeli a tényezőket. Gyakorlatias szemlélete, iparágcentrikus alapállása miatt Porter felvetései a régiók, térségek gazdaságfejlesztési stratégiájának kidolgozásához nagyon hasznosnak tủnnek: 
- Kiemeli a földrajzi koncentrációk elsödlegességét, a hazai bázison belül egyes iparágak térségi bázisának jelentőségét, azaz a globális versenyben a régiók fontosságát hangsúlyozza.

- Alapvetö, hogy rendszerszemléletben fogalmazza meg a térségek versenyképességének javítását, ami alatt a termelékenység növelését érti, ezáltal logikusan rendszerezhetök a térség jövőjével kapcsolatos elvárások, és a rombuszmodell felhasználásával kidolgozható a régió bottom-up gazdaságfejlesztési stratégiája.

- A globális versenyben a regionális klaszterek szerepét ismerte fel és kidolgozta a klaszter-alapú gazdaságpolitika alapelveit, amelyek a regionális gazdaságfejlesztésben felhasználhatók.

- Javaslatainak döntö része a magánszektor számára szól, azaz nem az önkormányzatoknak, mivel véleménye szerint a vállalatok közös érdeke olyan lokális üzleti környezet kialakítása, amely mindegyikük versenyelönyeit javítja, emiatt a vállalatok szívesen finanszírozzák a javasolt fejlesztéseket.

- A termelési tényezök újfajta rendszerezése, a speciális és a fejlett tényezők kiemelése lehetővé teszi a területi stratégiai programozás számára egy célpiramis, célhierarchia kialakítását az infrastruktúra és az üzleti környezet fejlesztéséhez.

- Nem a közigazgatási-statisztikai régiót tartja fontosnak, hanem a csomóponti régiót, a valóságos térbeli, időben is változó gazdasági szerveződést, iparágaktól is függö gazdasági kapcsolatrendszert.

- A vállalatok telephely-választását az értéklánc-rendszerre vezeti vissza, azaz iparáganként és értéklánc-elemenként más-más szempontok vezérlik a vállalati döntéshozókat, ebből következően a vállalati stratégia jellegétól függő́en még iparágon belül is eltérőek lehetnek a telepitési tényezők.

\section{Jegyzetek}

${ }^{1}$ A szerzö több területfejlesztési program munkáiban vett részt, többek között a Délalföldi régió gazdaságfejlesztési stratégiai programjának kidolgozását irányította.

${ }^{2}$ Az olyan iparágat nevezzük globálisnak, amelyben a versenyő́knek a helyi vagy regionális piacokon elért stratégiai pozícióját lényegében globális pozíciójuk határozza meg. A globális iparágakban a vállalatoknak világméretekben (globálisan) kell versenyezniük, különben stratégiailag hátrányba kerülnek.

${ }^{3}$ A vizsgálatbá bevont tíz ország: Dánia, Németország, Olaszország, Japán, Korea, Szingapúr, Svédország, Svájc, Egyesưlt Királyság, Amerikai Egyesült Államok. Az országok kiválasztása méret, elhelyezkedés alapján történt, ezen országok állították el̉ 1985-ben a világ exportjának mintegy $50 \%$-át. A tíz országban összesen 121 iparágat vizsgáltak.

${ }^{4}$ Magyar nyelvü publikációkban elöfordul a „gyémánt-modell” kifejezés is, viszont a négy csúcs egy négyszöget ír le, ezért megfelelöbbnek tartjuk a diamond szó ,rombusz alakú” fordítását.

5 Jórészt Porter tevékenységének köszönheb̋ a klaszterek újbóli elötérbe kerülése, a klaszter-alapú gazdaságfejlesztési elképzelések kidolgozása is. Megjegyezzük, hogy Porter az üzleti gazdaságtanok, föleg a menedzsment és a marketing szemléletéböl és fogalomkészletéböl indul ki, emiatt megállapitásait az elméleti közgazdászok fanyalogva fogadják, viszont a gyakorlati szakemberek, a vállalati, iparági stratégiákkal és a helyi gazdaságfejlesztési programozással foglalkozók nagy mértékben támaszkodnak munkáira. Michael Porter a Harvard Business School professzora, több alapkönyv szeröje, a 
versenystratégiák és versenyelönyök kidolgozásának egyik kezdeményezöje. A gazdasági szakemberek körében megfigyelhető elismertségét többek között az is jelzi, hogy az üzletembereket és gazdaságpolitikusokat tömöritő Világgazdasági Fórum (World Economic Forum) által évente készített Globális Versenyképességi Jelentés (The Global Competitiveness Report) társelnöke és egyik társszerzojje 1998 óta. Úgy tủnik, hogy napjainkban két közgazdaságtani irányzat járul hozzá a regionális tudomány megújulásához, az egyik Pauł Krugman térgazdaságtana, a másik pedig Michael Porter megközelítése (Benko 1999).

${ }^{6}$ Termelékenység alatt általában az egységnyi inputra (ráfordításra) jutó kibocsátást (output) értjük. Megkülönböztetjük a teljes termelékenységi mutatót, amely az inputok széles körére vonatkozik, az elsödleges tényezókre (föld, munka, tőke), valamint az egyéb inputokra (nyersanyag, energia, üzleti szolgáltatások, elosztás), illetve a részleges (vagy parciális) termelékenységi mutatókat, amelyek csak egyetlen inputféleségbö! indulnak ki ( $\mathrm{l} l$. a munkatermelékenység). A statisztikai gyakorlatban szokásos a kibocsátási index (volumenindex) és a foglalkoztatottsági index hányadosával mérni a termelékenység változását.

7 Megjegyezzuik, hogy Porter 1990-es könyvében még nem használja a versenyképesség (competitiveness) kifejezést, mivel hétköznapi elterjedtsége és többértelmüsége miatt nem tartja tudományos fogalomnak, helyette a nemzetek versenyelönye (competitive advantage of nation) szerepel. Viszont 1995-töl văltoztatott a véleményén, a versenyképesség kifejezés gyakran előfordul munkáiban, föleg a termelékenység szinonímájaként.

${ }^{8}$ Az 1990-es könyvében leirtakat részben módositotta, a rombuszmodellröl és hátteréröl kiváló leírás található az 1998-ban kiadott "On Competition" cimü tanulmánykötetében, amelyben munkásságának föbb eredményeit összegzi (Porter 1998a). Megjegyezzük, hogy a kötet három fejezetéböl a leghosszabb a „The Competitiveness of Locations” címü rész, ami utal arra is, hogy a stratégiai menedzsment egyik legelismertebb kutatója és oktatója a lokalitást tartja napjaink meghatározó gazdasági tényezöjének.

9 Megjegyezzük, hogy a hazai vállalatgazdaságtani egyetemi oktatás egyik tankönyve is Porter értéklánc koncepciójára épül (Chikán-Demeter 1999). Porter „,value system” kifejezését értéklánc-rendszerként használjuk, ez terjedt el a magyar gyakorlatban, a nemzetközi szakirodalomban a kissé eltérö tartalmú termelési lánc (production chain) vagy az ellátási lánc (supply chain) gyakoribb (Chikán 1998, 159-160).

${ }^{10}$ Agglomeráció alatt az egymás közelében, egyıás szomszédságában, egy térségben sürüsödő gazdasági tevékenységek együttesét értjük, amely lehet egy ipari körzet, avagy egy nagyváros és vonzáskörzete (Johnston-Gregory-Smith 1994). Agglomerációkból fakadó gazdaságosság (agglomeration economies): a gazdasági tevékenységek során a vállalatok, illetve a tevékenységek egymáshoz közeli elhelyezkedésébö! fakadó költségmegtakarítások, avagy más gazdasági elónyök, amelyek föleg a pozitív externhatásokból származnak, pl. nagy és szakképzett munkaeröpiac, fejlett szállitási és kommunkációs infrastruktúra, kedvezöbb közszolgáltatások stb. Az agglomeráció közgazdasági eredetü kifejezés, amelyböl következik a településtudományban használatos, a település-együttesekre vonatkozó fogalom (mint a mikroszervezetek: háztartások, intézmények és vállalkozások térbeli sürüsödése).

11 Porter az újabb modellben nem a termelési tényezök (factors of production), hanem a tényezö feltételek "factor (input) conditions" kifejezést használja (az 1990-es könyvben "factor conditions" szerepel), az iparági vizsgálatoknál pedig a hazai bázis tényezöellátottsága (factor endowment) áll elötérben. A hagyományos termelési tényezök közül a vállalkozói készség a rombuszmodell másik két determinánsához, a vállalati stratégiához és a támogató, kapcsolódó iparágakhoz került. Megjegyezzük, hogy a tényezóket az 1990-es könyvében még máshogy csoportosította (Hoványi 1999; Deák 2000).

${ }^{12}$ Nemcsak lakossági fogyasztási cikkekröl van szó, hanem a vállalatok által vásárolt inputokról: gépekröl, eszközökröl, nyersanyagokról, üzleti szolgáltatásokról stb. is. Sốt a hazai csúcstechnológiai cégek a legkifinomultabb vásárlók és elöre jelzik a piaci változások várható irányait.

${ }^{13}$ Az iparági versenyt meghatározza: az iparágban müködő versenytársak, a vevők és a szállítók alkupozíciója, a lehetséges belépök (ủj versenytársak) és a helyettesítỏ termékek fenyegetése (Porter 1993). 


\section{Irodalom}

Armstrong, H.-Taylor, J. (2000) Regional Economics and Policy. (third ed.) Blackwell, Oxford.

Benko, G. (1999) Regionális tudomány. Dialóg Campus, Budapest-Pécs.

Buzás N. (2000) Klaszterek: kialakulásuk, szervezödésük és lehetséges hazai regionális megjelenésük. Kézirat, SZTE Gazdaságtudományi Kar, Szeged.

Chikán A. (1998) Vállalatgazdaságtan. (második kiadás) Aula, Budapest.

Chikán A.-Demeter K. (szerk.) (1999) Az értékteremtő folyamatok menedzsmentje. Termelés, szolgáltatás, logisztika. Aula Kiadó, Budapest.

Cséfalvay Z. (1999) Helyünk a a nap alatt ... Magyarország és Budapest a globalizáció korában. Kairosz Kiadó/Nơvekedéskutató, Budapest.

Czakó E. (1997) Iparágak hazai és nemzetközi versenyképességét meghatározó tényezók. - GazdaságVállalkozás-Vezetés, 6-7. 18-24. o.

Deák Sz. (2000) A Porter-féle rombuszmodell főbb közgazdasági összefüggései. Kézirat, SZTE Gazdaságtudományi Kar, Szeged.

Drejer, I.-Kristensen, S.-Laursen, K. (1999) Cluster Studies as a Basis for Industrial Policy: The Case of Denmark. - Industry and Innovation. 2. 171-190. o.

Döry T. (1998) Beszállítói kapcsolatok és az ipari együttmüködés lehetséges klaszterei a KözépDunántúlon. - Tér és Társadalom. 3. 88-92. o.

Döry T.-Rechnitzer J. (2000) Regionális innovációs stratégiák. Oktatási Minisztérium, Budapest.

EC (1999a) Sixth Periodic Report on the Social and Economic Situation and Development of Regions in the European Union. European Comission, Luxembourg.

EC (1999b) The Structural Fund and Their Coordination with Cohesion Fund: Guidelines for programmes in the period 2000-06. Communication of the Commission. European Commission, Brussels.

Enyedi Gy. (1996) Regionális folyamatok Magyarországon az átmenet idöszakában. Hilscher Rezsö Szociálpolitikai Egyesület, Ember-telepiulés-régió sorozat, Budapest.

Enyedi Gy. (1997) A sikeres város. - Tér és Társadalom. 4. 1-9. o.

ESDP (1999) European Spatial Development Perspective. European Commission, Brussels.

Gordon, I.R.-McCann, P. (2000) Industrial Clusters: Complexes, Agglomeration and/or Social Networks. - Urban Studies. 3. 513-532. o.

Grosz A. (2000) Ipari klaszterek. - Tér és Társadalom. 2-3. 43-52. o.

Hatzichronoglou, T. (1996) Globalisation and Competitiveness: Relevant indicators. OECD STI Working Papers, Paris.

Hatzichronoglou, T. (1999) The Globalisation of Industry in the OECD Countries. OECD STI Working Papers, Paris.

Healy, M.J.-Dunham, P.J. (1994) Changing Competitive Advantage in a Local Economy: The Case of Coventry, 1971-90. - Urban Studies. 1279-1301. o.

Hill, E.W.-Brennan, J.F. (2000) A Methodology for Identifying the Drivers of Industrial Clusters: The Foundation of Regional Competitive Advantage. - Economic Development Quaterly. 1. 65-96. o.

Horváth Gy. (1998) Európai regionális politika. Dialóg Campus, Budapest-Pécs.

Hoványi G. (1999) A vállalati versenyképesség makrogazdasági és globális háttere. - Közgazdasági Szemle. 11. 1013-1029. o.

Johnston, R.J.-Gregory, D.-Smith, D.M. (eds) (1994) The Dictionary of Human Geography. (third ed) Blackwell, Oxford.

Kaufman, A.-Gittel, R.-Merenda, M.-Naumes, W.-Wood, C. (1994) Porter's Model for Geographic Competitive Advantage: The Case of New Hampshire. - Economic Development Quaterly. 1.43-66. o.

Korompai A. (1995) Regionális stratégiák jövókutatási megalapozása. ELTE Regionális Földrajzi Tanszék, Regionális Tudományi Tanulmányok. 1.

Lengyel I. (2000a) A regionális klaszterek fejlesztésének néhány alapkérdése. - Felzárkózás és EU. csatlakozás, -Román Z. (szerk.) MTA Ipar- és Vállalatgazdasági Bizottsága, Budapest, 274-281. o.

Lengyel I. (2000b) A regionális versenyképességröl. - Közgazdasági Szemle. 12.962-987. o.

Lengyel I.-Rechnitzer J. (2000) A vărosok versenyképességéröl. Magyarország terilleti szerkezetei és folyamatai az ezredfordulón. - Horváth Gy.-Rechnitzer J. (szerk.) MTA RKK, Pécs, 130-152. o.

Malecki, E.J. (1997) Technology and Economic Development: The dynamics of local, regional and national competitiveness. Longman, Edinburgh.

Malizia, E.E.-Feser, E.J. (1999) Understanding Local Economic Development. Center for Urban Policy Research, New Brunswick. 
Maskell, P.-Eskelinen, H.-Hannibalsson, I.-Malmberg, A.-Vatne, E. (1998) Competitiveness, Locational Learnings and Regional Development: Specialisation and prosperity in small open economies. Routledge, London.

OECD (1999) Boosting Innovation. The Cluster Approach. OECD, Paris.

O’Shaughnessy, N.J. (1996) Michael Porter's Competitive Advantage Revisited. - Management Decision. 6. 12-21. o.

Porter, M.E. (1985) Competitive Strategy. The Free Press, New York.

Porter, M.E. (1993) Versenystratégia. Akadémiai Kiadó, Budapest (eredeti: 1980).

Porter, M.E. (1990) The Competitive Advantage of Nations. The Free Press, New York.

Porter, M.E. (1996) Competitive Advantage, Agglomeration Economies, and Regional Policy. International Regional Science Review. 1-2. 85-94, o.

Porter, M.E. (1997) Clusters and Economic Development. Lecture on Workshop for Practioners in Cluster Formation, Chihuahua (Mexico).

Porter, M.E. (1998a) On Competition. The Free Press, New York.

Porter, M.E. (1998b) The Adam Smith Address: Location, Clusters, and the „New” Microeconomics of Competition. - Business Economics, 1. 7-14. o.

Porter, M.E. (1998c) Clusters and the New Economics of Competition. - Harvard Business Review. Nov-Dec. 77-90. o. (magyarul: Harvard Business Manager, 1999/4. 6-19. o.).

Porter, M.E. (1999) Microeconomics competitiveness: Findings from the 1999. Executive survey. World Economic Forum, Global Competitiveness Report. Davos, 30-53. o.

Porter, M.E. (2000) Location, Competition, and Economic Development: Local Clusters in a Global Economy. - Economic Development Quaterly. 1. 15-34. o.

Rechnitzer J. (1998) Terileti stratégiák. Dialóg Campus, Budapest-Pécs.

Rouvinen, P.--Yla-Anttila, P. (1999) Finnish Cluster Studies and New Industrial Policy Making. Boosting Innovation the Cluster Approach. OECD, Paris, 361-380. o.

Szentes T. (1998) Nemzeti fejlödés és „versenyképesség” a globalizálódás, transznacionalizálódás és integrációk korában. BKE Jubileumi Konferencia kötetei, 3. Budapest, 1681-1689. o.

Török Á. (1997) A versenyképesség-elemzés egyes módszertani kérdései. - Gazdaság-VállalkozâsVezetés. 3. 2-13. o.

Waits, M.E. (1998) Economic Development Strategies in the American States. Handbook of Economic Development. - Liou, K.T. (ed), Marcel Dekker, New York.

Waits, M.J. (2000) The Added Value of the Industry Cluster Approach to Economic Analysis, Strategy

Development, and Service Delivery. - Economic Development Quaterly. 1. 35-50. o.

\section{PORTER'S DIAMOND-MODEL FOR REGIONAL ECONOMIC DEVELOPMENT PROGRAMMING}

\section{IMRE LENGYEL}

In recent years, the issue of regional economic development has attracted a lot of attention and has been the subject of many studies in Hungary. The purpose of regional economic development is to increase economic prosperity, wage level and employment rate. The economic prosperity of regions is associated with their ability to generate economic activitjes which are able to improve their competitiveness.

This study tries to survey the Porter's diamond-model which is one of the well-known model of regional economic development programming. Porter measures a region's competitiveness on level of productivity and productivity growth. Porter identified four geographically development determinants that contributed to an industry's and/or region's competitive capabilities: (1) factor (input) conditions; (2) demand conditions; (3) related and supporting industries; (4) context for firm strategy and rivalry. These four determinants mutually reinforce one another and the interactions existing within a region. In Porter's theory, regional clusters have a prominent role. This study suggests that regional planners can make use of diamond-model of regional/local competitiveness. 